\title{
A neotype for Hyla x-signata Spix, 1824 (Amphibia, Anura, Hylidae)
}

\author{
Katyuscia Araujo-Vieiraa ${ }^{1,5}$; José P. Pombal Jr. ${ }^{2,6}$; Ulisses Caramaschi ${ }^{2,7}$; Gabriel Novaes-e-Fagundes ${ }^{3,8}$; \\ Victor G.D. Orrico ${ }^{3,9}$ \& Julián Faivovich ${ }^{1,4,10}$
}

\footnotetext{
1 Museo Argentino de Ciencias Naturales “Bernardino Rivadavia”, División Herpetología. Buenos Aires, Argentina. Consejo Nacional de Investigaciones Científicas y Técnicas (CONICET).

${ }^{2}$ Universidade Federal do Rio de Janeiro, Museu Nacional, Departamento de Vertebrados. Rio de Janeiro, RJ, Brasil.

3 Universidade Estadual de Santa Cruz, Programa de Pós-Graduação em Zoologia. Ilhéus, BA, Brasil.

${ }^{4}$ Universidad de Buenos Aires, Facultad de Ciencias Exactas y Naturales, Departamento de Biodiversidad y Biología Experimental. Buenos Aires, Argentina.

${ }^{5}$ ORCID: http://orcid.org/0000-0002-8193-2736. E-mail: katy.vieira@gmail.com (corresponding author)

${ }^{6}$ ORCID: http://orcid.org/0000-0003-4900-630X.E-mail: pombal@acd.ufrj.br

7 ORCID: http://orcid.org/0000-0003-1534-1038. E-mail:ulisses@acd.ufrj.br

${ }^{8}$ ORCID: http://orcid.org/0000-0002-4538-332X. E-mail: gnovaesefagundes@gmail.com

9 ORCID: http://orcid.org/0000-0002-4560-4006. E-mail: victordill@gmail.com

${ }^{10}$ ORCID: http://orcid.org/0000-0001-7157-8131. E-mail: julian@macn.gov.ar (corresponding author)
}

\begin{abstract}
The uncertain identity of Hyla $x$-signata Spix, 1824 has been a pervasive problem in the taxonomy of the genus Scinax. A species supposedly distributed from northeastern Brazil northwards to Colombia and Venezuela, described in a few lines without much information and with an accompanying figure, and its type specimen lost during World War Il, combined to produce a curious situation. Twenty-one of the 39 species of the S. ruber Clade described in the last 50 years were considered to require a diagnosis from $S . x$-signatus by their authors. In most cases these had no other alternative than to gather information about this species from indirect sources, frequently pointing out the problems associated with its uncertain identity. In this paper, we review the taxonomic history of Hyla $x$-signata, designate a neotype, provide a redescription including advertisement call and sequence data, and diagnose it from all other species of the S. ruber Clade.
\end{abstract}

Key-Words. Hylinae; Scinaxini; Scinax; Scinax ruber.

\section{INTRODUCTION}

Scinax currently includes 125 species in two major clades, the S. catharinae and the S. ruber Clades (species number from Frost, 2020; taxonomy of Scinaxini as recognized by Faivovich et al., 2018). The latter clade includes 75 species; three in the S. uruguayus species Group (Faivovich et al., 2005; Baldo et al., 2019), 10 in the S. rostratus species Group (Lima et al., 2005), and 62 unassigned to any species group. These are mostly the result of a phylogenetic analysis (Faivovich, 2002) that rejected the monophyly of most species groups recognized at that time for the species now included in the S. ruber Clade. Subsequent analyses (Wiens et al., 2010; Duellman et al., 2016) corroborated that result, always with a low density of exemplar species of the clade, and therefore without the possibility of recognizing monophyletic groups of taxonomic relevance. While this situation alone requires extensive diagnoses every time a new species is described, the efforts are magnified by the complicated taxonomy of these frogs, and some confusion persists regarding the identity of certain species. One of these is S. $x$-signatus (Spix, 1824), a putatively widespread species whose identity has been, for nearly 70 years, a specter of doubt hunting the taxonomy of several species of Scinax.

A species supposedly distributed from northeastern Brazil northwards to Colombia and Venezuela, described in a few lines without much information and with an accompanying figure, and its type specimen lost during World War II (Hoogmoed \& Gruber, 1983; Glaw \& Franzen, 2006), combined to produce a curious situation. Twenty-one of the 39 species of the S. ruber Clade described in the last 50 years were considered to require a diagnosis from $S$. $x$-signatus by their authors (e.g., Bokermann, 1968; Pombal et al., 1995a; Barrio-Amorós et al., 2004; Sturaro \& Peloso, 2014; Araujo-Vieira et al., 2016; Acosta-Galvis, 2018). In 
most cases, these had no other alternative than to gather information about this species from indirect sources, frequently pointing out the problems associated with its uncertain identity. In this paper, we review the taxonomic history of Hyla $x$-signata, designate a neotype, provide a redescription of the species, and diagnose it from all other species of the S. ruber Clade.

\section{MATERIAL AND METHODS}

\section{Adult morphology}

Collected specimens were euthanized in 5\% lidocaine, fixed in $10 \%$ formalin, and preserved in $70 \%$ ethanol. The neotype specimen was deposited in the Célio F.B. Haddad collection (CFBH - Universidade Estadual Paulista, Rio Claro, São Paulo, Brazil). Institutional abbreviations listed in Appendix 1 follow Sabaj (2019), complemented with MHNJCH (Museu de História Natural de Jequié-Coleção Herpetológica, Universidade Estadual do Sudoeste da Bahia, Jequié, Bahia, Brazil). Observations on other species of the Scinax ruber Clade are based on preserved specimens (see Appendix 1) supplemented with information from the literature: Rivero (1961); Bokermann (1968, 1969); Pyburn \& Fouquette (1971); Lutz (1968, 1973); Duellman (1970, 1971, 1972a, b, 1973, 1986); Fouquette \& Pyburn (1972); Bokermann \& Sazima (1973); Cardoso \& Sazima (1980); De la Riva (1990, 1993); Heyer et al. (1990); Henle (1991); Duellman \& Wiens (1992, 1993); Pyburn (1973, 1992, 1993); Pombal et al. (1995a); Lescure \& Marty (2000); La Marca (2004); Lima et al. (2005); Pugliese et al. (2004, 2009); Caramaschi \& Cardoso (2006); Drummond et al. (2007); Moravec et al. (2009); Nunes et al. (2010, 2012); Nunes \& Pombal (2010, 2011); Hoogmed \& Avila-Pires (2011); Brusquetti et al. (2014); Araujo-Vieira et al. (2015, 2016); Juncá et al. (2015); Conte et al. (2016); Ferrão et al. (2017, 2018a, b); Acosta-Galvis (2018); Ron et al. (2018); and Baldo et al. (2019).

Measurements (in millimeters) were taken with a digital caliper, and rounded to the nearest $0.1 \mathrm{~mm}$ (Table 1). Eye diameter (ED), eye-nostril distance (EN), foot length

Table 1. Measurements (in $\mathrm{mm}$ ) of Scinax $x$-signatus (including the neotype). See Materials and methods for the abbreviations of measurements.

\begin{tabular}{cccccc}
\hline \multirow{2}{*}{ Measurements } & \multicolumn{2}{c}{ Females $(\boldsymbol{n}=\mathbf{3})$} & & \multicolumn{2}{c}{ Males $(\boldsymbol{n}=13)$} \\
\cline { 2 - 3 } \cline { 5 - 6 } \cline { 5 - 6 } SVL & Range & Mean \pm SD & & Range & Mean \pm SD \\
\hline HL & $32.9-44.7$ & $38.6 \pm 5.9$ & & $34.5-38.4$ & $36.7 \pm 1.2$ \\
HW & $11.6-15.0$ & $13.2 \pm 1.7$ & & $11.2-13.0$ & $12.2 \pm 0.6$ \\
IND & $10.7-14.1$ & $12.3 \pm 1.7$ & & $9.3-12.5$ & $11.6 \pm 0.7$ \\
IOD & $1.1-3.3$ & $2.2 \pm 1.1$ & & $2.0-2.5$ & $2.3 \pm 0.1$ \\
ED & $3.6-4.7$ & $4.2 \pm 0.6$ & & $3.0-3.8$ & $3.3 \pm 0.3$ \\
EN & $3.4-3.9$ & $3.7 \pm 0.3$ & & $3.4-4.1$ & $3.6 \pm 0.2$ \\
TD & $3.6-5.2$ & $4.4 \pm 0.8$ & & $3.5-4.2$ & $3.8 \pm 0.2$ \\
FL & $2.4-3.1$ & $2.6 \pm 0.4$ & & $2.2-2.9$ & $2.6 \pm 0.2$ \\
TL & $12.7-19.7$ & $15.8 \pm 3.6$ & & $12.5-15.6$ & $14.5 \pm 0.5$ \\
3FD & $16.6-24.2$ & $19.9 \pm 3.9$ & & $17.0-19.0$ & $17.9 \pm 0.5$ \\
4TD & $1.4-2.1$ & $1.7 \pm 0.3$ & & $1.5-2.1$ & $1.7 \pm 0.2$ \\
\hline
\end{tabular}

$(F L)$, head length $(H L)$, head width $(H W)$, internarial distance (IND), interorbital distance (IOD), snout-vent length (SVL), tympanum diameter (TD), and tibia length (TL) were taken following Duellman (1970); third finger disc diameter (3FD) and fourth toe disc diameter (4TD) follow Napoli \& Caramaschi (1998).

Fingers were numbered II to V following Fabrezi \& Alberch (1996). Webbing formula follows Savage \& Heyer (1967) as modified by Myers \& Duellman (1982). Dorsal and profile standards of snout shape follow Heyer et al. (1990). Nuptial pad terminology is that of Luna et al. (2018). Sex was determined by examination of secondary sexual characters (nuptial pads, vocal slits, and vocal sacs) or dissections.

Muscles were studied with a Lugol solution to enhance contrast (Bock \& Shear, 1972). We considered three morphologies of external, subgular vocal sacs: single, weakly bilobate, and bilobate (modified from Duellman, 1970). They correspond anatomically to three different configurations of the subgular portion of the m. interhyoideus. In single vocal sacs, the m. interhyoideus does not have a medial constriction in its posterior portion, forming a uniform lobe. In weakly bilobate vocal sacs, the $\mathrm{m}$. interhyoideus has a slight medial constriction in its posterior portion, forming small but continuous contralateral lobes. In bilobate sacs, the $\mathrm{m}$. interhyoideus has a conspicuous medial constriction in its posterior portion, forming a discrete lobe on each side of the subgular region.

\section{Advertisement call}

The advertisement call description was based on recordings from the neotype, and other six males from three localities in the State of Bahia, Brazil complemented with the acoustical data of two specimens (MHNJC 1014 and unvouchered) from Contendas do Sincorá, Bahia reported by Novaes \& Zina (2016). Information on call measurements, recording, voucher number, SVL, and air temperature are shown in Table 2. Call recordings of Scinax $x$-signatus produced for this study are deposited in the Fonoteca Zoológica (FonoZoo), Museo Nacional de Ciencias Naturales (MNCN), Consejo Superior de Investigaciones Cientificas (CSIC), Madrid, Spain. Comparisons with advertisement calls of other species of the $S$. ruber Clade are based on the descriptions by León (1969); Pyburn \& Fouquette (1971); Duellman (1972a, b, 1973, 1986); Pyburn (1973); De la Riva (1993); De la Riva et al. (1994); Pombal et al. (1995a, b, 2011); Lescure \& Marty (2000); Bevier et al. (2008); Magrini et al. (2011); Brusquetti et al. (2014); Pugliese et al. (2004); Carvalho et al. (2015, 2017); Mângia et al. (2017); and Ferrão et al. (2018b).

Recordings were made with Marantz PMD660, PMD661MKII, or Tascam DR40 digital recorders, coupled with a Sennheiser ME66 directional microphone from a distance of 0.5-1.0 m from the individual. Calls were recorded and digitized in uncompressed PCM and WAV formats with a sample rate of $44.1 \mathrm{kHz}$ or $48 \mathrm{kHz}$ and 16-bit encoding. Call analyses were performed with Raven Pro 


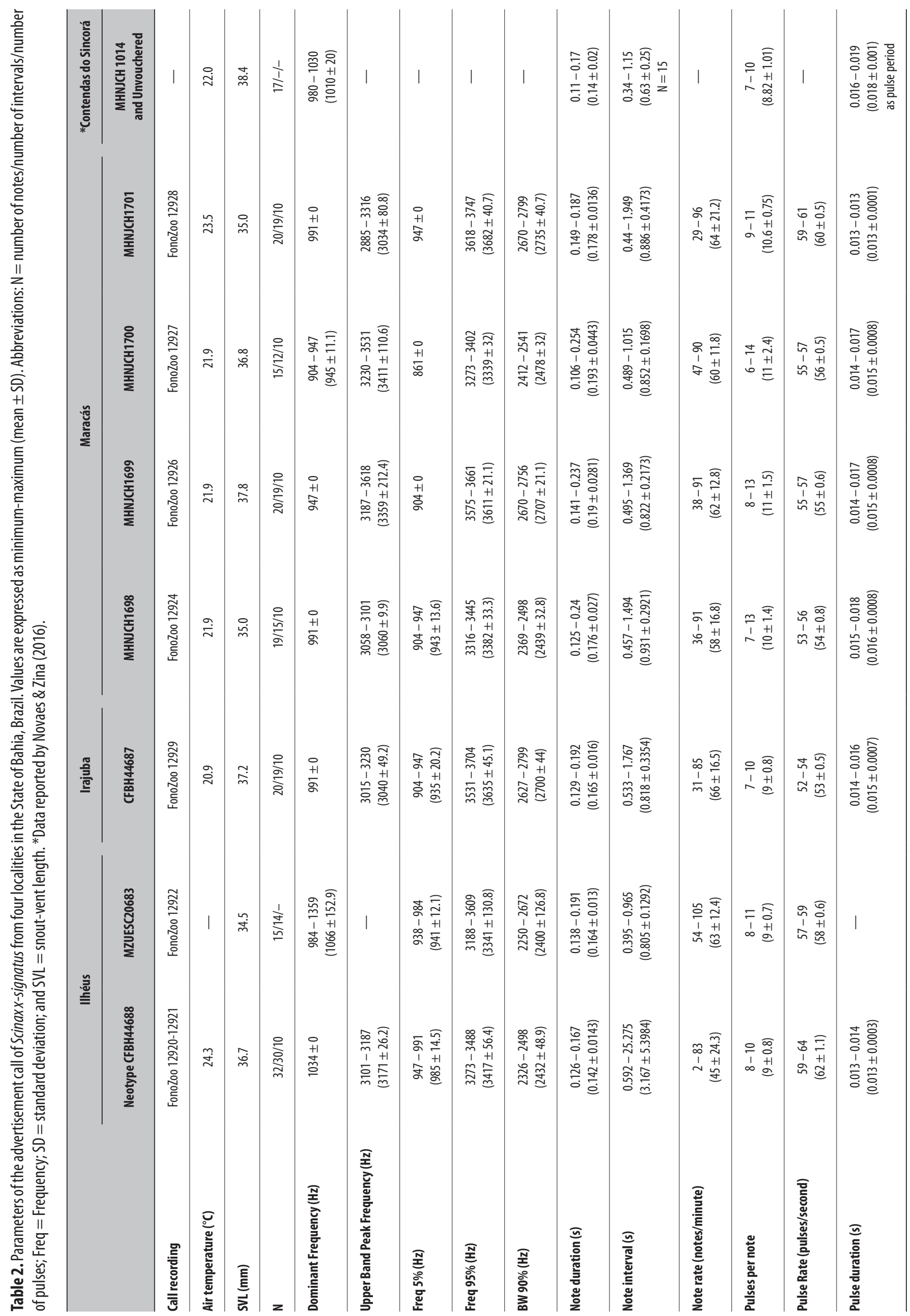


1.6 software (Bioacoustics Research Program, 2019) with window type Hann, window and DFT size of 1,024 samples, time grid with $90 \%$ overlap. If necessary, we filtered the frequencies above and below the bandwidth of the call, to reduce interference from environmental sounds (usually below $500 \mathrm{~Hz}$ and above 5,500 Hz).

Temporal parameters were measured from waveforms, whereas spectral parameters were measured from spectrograms. We use the term "note" as defined by Köhler et al. (2017): subunits of a call that are separated by $100 \%$ amplitude modulation with only short intervals between them relative to length of note.

For the calls analyzed in this study, we selected 15-32 notes from each recorded male, comprising a total of 141 notes. We delimited the selection borders (i.e., beginning and end) of each note using the threshold of $10 \%$ of its maximum amplitude (see Littlejohn, 2001). From each selection we took the following Raven Pro auto measurements (see Charif et al., 2010 for definitions): note duration (delta time), dominant frequency (peak frequency), frequency 5\% (freq5\%), frequency 95\% (freq95\%), bandwidth $90 \%$ (BW90\%). We also measured manually the interval between notes, note repetition rate (notes per minute), number of pulses per note, pulse repetition rate (pulses per second), and pulse duration (measured from the pulse with the highest amplitude in 10 notes from each individual using the threshold of $10 \%$ of its maximum amplitude). We did not measure the pulse duration of the call of MZUESC 20683 due to the recording's suboptimal waveform resolution.

\section{Phylogenetic analysis}

We performed a phylogenetic analysis with the sole goal of testing the identification of all sequences in GenBank that had been associated with Scinax $x$-signatus in different publications (Fouquet et al., 2007a, b; Lyra et al., 2016; Vacher et al., 2020). We included sequences of the 16S rRNA mitochondrial gene for 28 specimens of S. $x$-signatus, including the neotype, from some localities in the Brazilian states of Bahia, Ceará, Pernambuco (including the Island Fernando de Noronha, introduced), and Amapá, and also from French Guiana and Martinique. One sequence associated with S. x-signatus (KU495577; Lyra et al., 2016) from Itabuna, Bahia, was excluded from the analysis because the tissue sample (CFBHt 03433) is associated with a specimen of S. argyreornatus (CFBH 2890) that belongs to the S. catharinae Clade. We also included sequences for one related lineage to S. $x$-signatus (S. x-signatus "Scinax_64" in Vacher et al., 2020), specimens of S. eurydice, S. fuscovarius, S. nasicus, S. ruber, and $S$. similis - species that share some morphologically similarities with S. $x$-signatus -, and S. berthae, S. catharinae (S. catharinae Clade), and Sphaenorhynchus lacteus (Sphaenorhynchini) as outgroup taxa. The dataset includes 52 terminals, of which sequences of twelve were produced for this study; the remaining corresponds to sequences from GenBank. See Appendix 2 for a complete list of voucher specimens included in the analysis.
For sequences produced in this study, whole cellular DNA was extracted from frozen and ethanol-preserved tissues (liver or muscle) using either phenol-chloroform extraction methods or the Qiagen DNeasy isolation kit. Primers used in PCR amplification were 16sAR (5'-CGCCTGTTTATCAAAAACAT-3'; Palumbietal., 1991) and 16sWilk2 (5'-GACCTGGATTACTCCGGTCTGA-3'; Wilkinson et al., 1996) or 16sBR (5'-GACCTGGATTACTCCGGTCTGA-3'; Palumbi et al., 1991). PCR amplification was carried out in $25 \mu \mathrm{l}$ reactions using $0.2 \mu \mathrm{l} \mathrm{Taq}$ (Fermentas). The PCR protocol consisted of an initial denaturation step of 3 minutes at $94^{\circ} \mathrm{C}, 35$ cycles of $30 \mathrm{~s}$ at $94^{\circ} \mathrm{C}, 40 \mathrm{~s}$ at $48^{\circ} \mathrm{C}$, and $30-60 \mathrm{~s}$ at $72^{\circ} \mathrm{C}$, and a final extension step of 10-15 minutes at $72^{\circ} \mathrm{C}$. The PCR amplified products were cleaned with $0.5 \mu \mathrm{L}$ of Exonuclease plus $1 \mu \mathrm{L}$ of Alkaline Phosphatase per $20 \mu \mathrm{L}$ of reaction. Sequencing was carried out on an automatic sequencer $\mathrm{ABI}$ 3730XL (Applied Biosystems) in both directions to check for potential errors and polymorphisms. The chromatograms obtained from the automated sequencer were read, contigs made using the sequence editing software Sequencher v5.3 (Gene Codes, Ann Arbor, MI, USA), and edited the complete sequences with BioEdit (Hall, 1999).

We performed a multiple sequence alignment of the 16S rRNA fragments employing MAFFT v.7 (Katoh \& Standley, 2013; default parameters). For the parsimony analysis, we employed TNT v1.5 Willi Hennig Society Edition (Goloboff et al., 2008; Goloboff \& Catalano, 2016; equal costs for all transformations, gaps treated as fifth state). The shortest trees were found using the option "Traditional Search" performing a large number of random addition sequences (RAS, usually 300-500), retaining five trees per replicate, and then submitting them to a round of tree bisection and reconnection (TBR) branch swapping. All searches were done under the collapsing option "minimum length", which collapses every node whose minimum length is 0. Parsimony jackknife absolute frequencies (Farris et al., 1996) were calculated in TNT v1.5 using traditional search requesting 100 RAS+TBR, retaining five trees per replicate for a total of 1,000 replicates. Trees were edited with FigTree v1.4.3 (Rambaut, 2016). Uncorrected pairwise distances were calculated in PAUP* (Swofford, 2002) for specimens of S. $x$-signatus and the related lineage S. $x$-signatus "Scinax_64". Most vouchers specimens of $S$. $x$-signatus were studied to corroborate their specific identity; exceptions were the specimens from sequences produced by Fouquet et al. (2007a, b) and Vacher et al. (2020) that were not available for examination (see Appendix 2).

\section{RESULTS}

\section{Historical resume}

Hyla $x$-signata was illustrated and briefly described by Spix (1824), based on a single specimen collected in "Provincia Bahiae" (part of the current State of Bahia, east of the Rio São Francisco, Brazil; see Vanzolini, 1981). The first reference to $H$. $x$-signata after the original de- 
scription was by Wagler (1830). In a footnote to the description of the genus Enydrobius, a replacement name for Hylodes Fitzinger, 1826 (currently considered a synonym of Hylodes), Wagler (1830) stated that H. $x$-signata was very similar to the two species included in this genus. Duméril \& Bibron (1841) considered H. $x$-signata to be a synonym of $H$. rubra Daudin, 1802 (which is $H$. rubra Laurenti, 1768: 35; see León, 1969 and Duellman \& Wiens, 1993). They based this conclusion on the variation in dorsal pattern observed in specimens identified as the latter species; some of them showed the two X-shaped marks, which they associated with the pattern described and illustrated by Spix (1824). This position was followed by Burmeister (1856) and Günther (1858). Cope (1870), instead, included H.x-signata in the genus Scytopis Cope, 1862 (currently a synonym of Trachycephalus Duellman, 1971; Faivovich et al., 2005).

However, Peters (1872) was the only herpetologist to explicitly report on the type specimen of Hyla $x$-signata. He stated that it was similar with $H$. rubra, but differed in the marbled reticulation of the anterior and posterior surfaces of thighs and the presence of granules on the dorsum, considering it a variety, $H$. rubra var. $x$-signata. Cope (1874) still considered $H$. $x$-signata as a valid species of Scytopis, distinct from H. rubra. Boulenger (1882) treated $H$. $x$-signata as a synonym of $H$. rubra and described the dorsal pattern with $\mathrm{X}$-shaped marks as one of the two commonly occurring patterns in this species. Subsequently, the references in the literature to $H . x$-signata are scarce, including it as a synonym of $H$. rubra (e.g., Berg, 1896; Nieden, 1923), a variety (Baumann, 1912), or a subspecies (Müller, 1927) of the latter, or a related form of uncertain status (Lutz, 1951).

The uncertainties regarding the taxonomic status of Hyla $x$-signata were only magnified by the fact that the collection of the Zoologisches Staatssammlung München, Germany, which housed most types of Spix, was partially destroyed during a bombing in World War II. While many type specimens are still extant, the holotype of $H$. x-signata (ZSM 2494/0) has long been considered lost (Hoogmoed \& Gruber, 1983; Glaw \& Franzen, 2006).

Cochran $(1952,1955)$ considered Hyla $x$-signata as a valid species that she thought closely related with the then $H$. similis and $H$. fuscovaria, stating the need to study fresh material. Gallardo (1961) and Bokermann (1966) also considered $H$. $x$-signata as a valid species. Rivero (1961) stated that he preferred not to associate specimens of $H$. rubra from Venezuela to its described subspecies - listing $H$. rubra var. $x$-signata, among others - until the species is better studied. Rivero (1969) discussed the status of $H$. rubra and $H$. $x$-signata, comparing specimens mostly from Venezuela, and considered them as different species, while Cochran \& Goin (1970) considered H. $x$-signata as a synonym of $H$. rubra. From this point on, multiple authors referred to the occurrence of Scinax $x$-signata in Colombia, Venezuela, and the Guianas (León-Ochoa, 1975; Hoogmoed, 1979; Hoogmoed \& Gorzula, 1979; Rivero-Blanco \& Dixon, 1979; Rada de Martinez, 1981; Ramo \& Busto, 1990; Barrio-Amorós, 1998; Gorzula \& Señaris, 1998; Barrio-Amorós et al., 2004, 2011, 2019;
Tárano, 2010; Ugueto \& Rivas-Fuenmayor, 2010; Suárez \& Lynch, 2011; Señaris et al., 2014; Acosta-Galvis, 2018). However, some of them expressed concerns of whether the name was being correctly applied (Lescure \& Marty, 2000; Ouboter \& Jairam, 2012; Cole et al., 2013; BarrioAmorós et al., 2011, 2019), arguing that several species were currently associated with that name at least in Venezuela (Barrio-Amorós et al., 2011, 2019).

Lutz (1973) recognized Hyla $x$-signata as a valid species and provided an extensive characterization based on multiple specimens from several localities in Brazil. Furthermore, she considered several species recognized at that time $(H$. nasica Cope, $1862 ; H$. similis Cochran, 1952; H. eringiophila Gallardo, 1961; and $H$. camposseabrai Bokermann, 1968) as subspecies of $H$. x-signata. With different taxonomic trajectories (not relevant here), all these subspecies eventually were returned to species status (Fouquette \& Delahoussaye, 1977; Langone \& Cardoso, 1997; Caramaschi \& Cardoso, 2006).

Pombal et al. (1995a) noticed that the lost holotype of Scinax $x$-signatus, the original description, and subsequent descriptions (Rivero, 1969; Lutz, 1973; Heyer et al., 1990) precluded a correct identification of this species. For that reason, they excluded it from their diagnosis of the new species from southeastern Brazil that they described ( $S$. perereca). Subsequent papers adopted a similar position (Pombal et al., 1995b; Pugliese et al., 2004, 2009; Drummond et al., 2007; Nunes \& Pombal, 2010, 2011; Nunes et al., 2010). Some authors extracted information from the illustration included in the original description (e.g., Nunes et al., 2012; Ferrão et al., 2017; Sturaro \& Peloso, 2014) or the account provided by Lutz (1973) for Brazilian populations that she associated with that name (Juncá et al., 2015; Araujo-Vieira et al., 2016; Conte et al., 2016). Other authors compared collection specimens identified as $S$. $x$-signatus without further comment (Barrio-Amorós et al., 2004; Caramaschi \& Cardoso, 2006; Ferrão et al., 2018a, b; Acosta-Galvis, 2018). Considering the limitations imposed by the uncertain identity of S. $x$-signatus, some authors stated the need of having a neotype designated (Pugliese et al., 2009; Sturaro \& Peloso, 2014; Araujo-Vieira et al., 2015; Sichieri et al., 2019).

\section{A neotype for Hyla x-signata}

The need to designate a neotype for Hyla x-signata is well justified because it will clarify the status of this species, and of the several species to which the name has been applied throughout its wide distribution. The International Code of Zoological Nomenclature (ICZN, 1999) establishes (art. 75.1) that a neotype can be designated "when no name-bearing type specimen (...) is believed to be extant and an author considers that a name-bearing type is necessary to define the nominal taxon objectively." Qualifying conditions established by the ICZN (1999) when describing a neotype include "the author's reasons for believing the name-bearing type specimen (s)... to be lost or destroyed, and the steps that 
had been taken to trace it..." (art. 75.3.4); the existence of "evidence that the neotype is consistent with what is known of the former name-bearing type from the original description and from other sources..." (art. 75.3.5); and "evidence that the neotype came as nearly as practicable from the original type locality..." (art. 75.3.6).

As for the first qualifying condition, Lutz (1973) commented that the holotype of Hyla $x$-signata was lost, considering it destroyed during World War II, as did Duellman (1977). This fact was corroborated by Hoogmoed \& Gruber (1983) on their thorough study on the status of Spix's types, and more recently, by Glaw \& Franzen (2006). A recent inquire to the Zoologischer Staatssamlung München corroborated that the holotype is still considered lost (Frank Glaw, pers. comm.).

As for the second qualifying condition, the available, direct evidence on the holotype of Hyla $x$-signata stems from the original description and figure by Spix (1824), and the comments on the type specimen by Peters (1872). The description of $H$. $x$-signata by Spix (1824) is not particularly informative, except for a reference to two $\mathrm{X}$-shaped marks on the dorsum ("... dorsum maculis binis $x$-formibus signatum..."), and a curious mention of "digiti ranaeformes". Otherwise, it is similar in terms of the morphological description to other hylids described in the same book [e.g., H. nebulosa (currently Scinax nebulosus) and $H$. strigilata (currently S. strigilatus; see Pimenta et al., 2007)]. The figure (here reproduced as Fig. 1), however, clearly depicts the typical dorsal pattern showing a pair of inverted parentheses on the dorsum, that occurs in

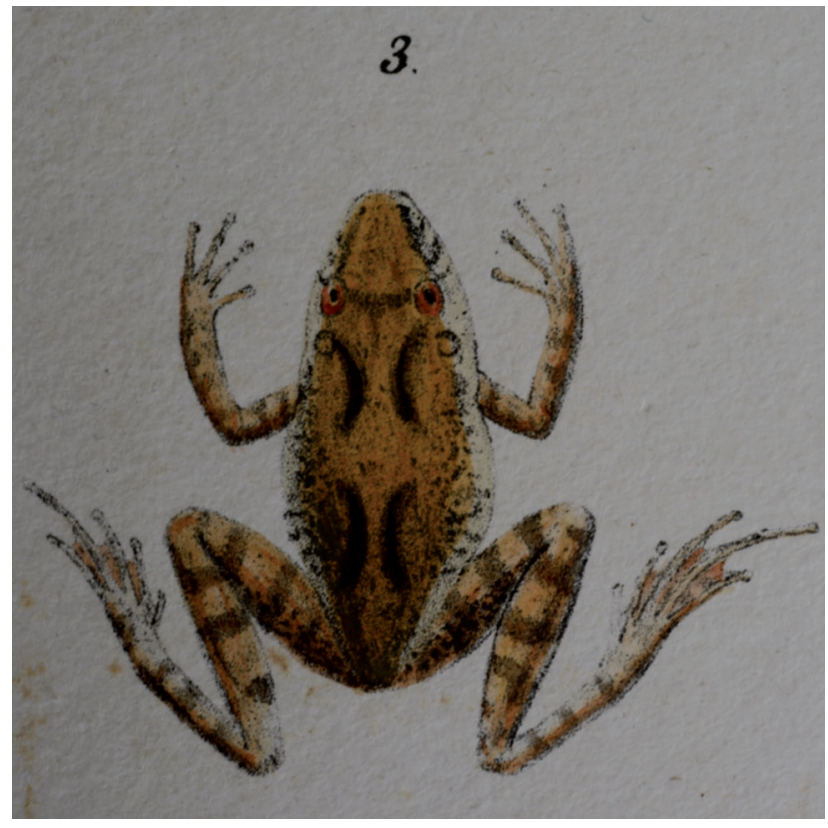

Figure 1. Specimen of Hyla $x$-signata figured and described by Spix (1824: plate XI, fig. 3). Note that the reproduced figure is from the 1839 reprint of the Ranarum section alone, housed in the MACN central library. The illustrations of the reprints were printed from the same metal plates of the first edition (Adler, 1981). There are some differences in the coloring of the figures among editions, and the one reproduced here has some subtle differences in the flanks and sides of the head. Please refer to the digital version of the 1824 edition in Biodiversity Heritage Library (https://www.biodiversitylibrary.org/ item/21828\#page/119/mode/1up). several species of Scinax (such as S. camposseabrai, S. eurydice, S. fuscovarius, S. granulatus, S. nasicus, some specimens of S. similis, and the populations that have been associated with S. $x$-signatus, from NE Brazil to Colombia).

If the description by Spix (1824) had some ambiguous reference, such as the raniform digits, the comments by Peters (1872) on the type specimen should dispel any doubt of its similarity with Hyla rubra, or at least with hylids that could be confused with that species. Peters (1872) stated that the type specimen is overall comparable with $H$. rubra, from which it differs by the reticulated pattern on the hidden surfaces of the thigh, and the occurrence of granules on the dorsum. He compared the type specimen with two specimens from the surroundings of Rio de Janeiro (ZMB 5922) that unfortunately could not be located in the Berlin Museum collection (Frank Tillack, pers. comm., 24 July 2020).

The comments by Wagler (1830), Müller (1927), and Cochran $(1952,1955)$ on Hyla $x$-signata are considered as indirect evidence since, although the first two very likely had contact with the type specimen, they made no direct reference to it. Wagler (1830) referred to $H$. $x$-signata in a footnote to the description of the genus Enydrobius, a replacement name for Hylodes Fitzinger, 1826. He stated that Hyla $x$-signata was very similar to the two species included in this genus [H. ranoides Spix, 1824 (a synonym of $H$. nasus Lichtenstein, 1823; currently Hylodes nasus) and Hyla abreviatta Spix, 1824 (a synonym of Rana binotata Spix, 1824; currently Haddadus binotatus)], a comment that is certainly confusing. It could be assumed that Wagler had direct knowledge of the type specimen of Hyla $x$-signata given his involvement in the study of the collection amassed by Spix during his travels (Vanzolini, 1981). However, it is noticeable that Peters (1872), when studying the types of Hylodes ranoides and Rana binotata made no reference to Wagler's comment (1830) nor Hyla x-signata, that in the same paper he associated with H. rubra a few pages ahead.

Lorenz Müller (1868-1953) was in charge of the herpetological collection of the Zoologischer Staatssamlung München. Although Müller (1927) did not explicitly state that his conclusion that Hyla $x$-signata is a subspecies of $H$. rubra was based on the type specimen of the former species, it is likely so (as also assumed by Hoogmoed \& Gruber, 1983). Doris M. Cochran (1898-1968) visited ZSM in October 1938 (Heyer in Hoogmoed \& Gruber, 1983), where she studied some of Spix's types. Unlike other cases (e.g., H. strigilata), Cochran $(1952,1955)$ did not list the type specimen in the list of specimens examined following the only mention of that species in her study - in the account of $H$. similis. This absence could indicate that she did not see the type specimen or that she did not consider this species to occur in the area of her study of 1955 (the Brazilian states of Minas Gerais, Rio de Janeiro, and São Paulo). In any case, she stated that H. x-signata was "apparently nearest to [Hyla] similis, after [Hyla] fuscovaria, but fresh Bahian material is needed before an exact comparison can be made." As a synthesis, with the exception of the statements by Wagler (1830) that we consider to be implicitly contested by Peters (1872), all 
the available evidence indicates that the type specimen of $H$. $x$-signata corresponded to a hylid similar to Scinax ruber and other species of Scinax, and it had a dorsal pattern with two pairs of inverted parentheses, the typical X-shaped markings.

Regarding the third qualifying condition, Spix (1824) stated the type locality as "Provincia Bahiae", an expression that, according to Vanzolini (1981), refers to the ancient limits of the State of Bahia, which correspond to the current limits, east of the river São Francisco. The itinerary followed by Spix and Martius in Bahia is well known (Papavero, 1971; Vanzolini, 1981), having entered the limits of that province from the west, and covered several localities from Malhada to Salvador (e.g., Caetité, Rio de Contas, Maracás, Santa Teresinha, São Félix, Salvador), and Ilhéus and surrounding localities (e.g., Camamu, Itabuna, Itacaré). We designate a neotype for Hylax-signata collected in Ilhéus. Furthermore, we have specimens of the same species collected in some other localities visited by Spix.

\section{Scinax x-signatus (Spix, 1824)}

Hyla x-signata Spix, 1824.

Hyla affinis Spix, 1824 - Considered a synonym of Hyla $x$-signata by Hoogmoed \& Gruber (1983). Sturaro \& Peloso (2014) questioned this association based on the description and figure provided by Spix (1824). Our study of photographs of the holotype (ZSM 2945 ) indicates that the situation is uncertain. Only a study of the taxonomy of amazonian populations associated with Scinax $x$-signatus would allow to clarify the status of this nomen.

Hyla coerulea Spix, 1824 - Considered a synonym of Hyla $x$-signata by Hoogmoed \& Gruber (1983). Sturaro \& Peloso (2014) questioned this association based on the description and figure provided by Spix (1824). Our study of photographs of the lectotype designated by Hoogmoed \& Gruber (1983) (ZSM 2710-0-1) indicates that the situation is uncertain. Only a study of the taxonomy of amazonian populations associated with Scinax $x$-signatus would allow to clarify the status of this nomen.

Hyla rubra Daudin, 1802 (part) - Duméril \& Bibron, 1841. First treatment as a synonym of Hyla rubra Laurenti, 1768 (not Daudin, 1802; see León, 1969; Rivero, 1969; Duellman \& Wiens, 1993).

Scytopis xsignatus [sic] - Cope, 1870. First combination with Scytopis Cope, 1862.

Hyla rubra var. $x$-signata - Peters 1872 . First treatment as a variety of Hyla rubra Laurenti.

Hyla rubra x-signata - Müller, 1927. First treatment as a subspecies of Hyla rubra Laurenti, 1768.

Hyla x-signata $x$-signata - Lutz, 1973. First use as nominal subspecies.

Ololygon x-signata - Fouquette \& Delahoussaye, 1977. First combination with Ololygon Fitzinger, 1843.

Scinax $x$-signata - Duellman \& Wiens, 1992. First combination with Scinax Wagler, 1830.

Scinaxx-signatus - Köhler \& Böhme, 1996. Gender change.

\section{Neotype}

CFBH 44688, adult male, campus of the Universidade Estadual de Santa Cruz - UESC, Salobrinho, Ilhéus, State of Bahia, Brazil [39 $10^{\prime} 24^{\prime \prime} \mathrm{W}, 14^{\circ} 47^{\prime} 52^{\prime \prime} \mathrm{S}$; about $30 \mathrm{~m}$ above sea level (a.s.l.)], collected 10 April 2018 by G. Novaes-e-Fagundes. urn:Isid:zoobank. org:act:F357D8CC-446B-4F2C-9B53-190AFEEFD533

\section{Referred specimens}

Fifteen adults (12 males and three females) from eight localities in the State of Bahia, Brazil. CFBH 21071 (male), Povoado Senote, Caetité $\left(42^{\circ} 28^{\prime} 48^{\prime \prime} \mathrm{W}, 14^{\circ} 04^{\prime} 55^{\prime \prime} \mathrm{S}\right)$; MHNJCH 1014 (male), Floresta Nacional Contendas do Sincorá, Contendas do Sincorá $\left(41^{\circ} 07^{\prime} 04^{\prime \prime} \mathrm{W}\right.$, 1355'20"S); MZUESC 20683 (male), Condomínio Parque Universitário, Salobrinho, Ilhéus (39¹0'43"W, 1447'44"S); CFBH 44687 (male), Fazenda Lagoa Nova, Irajuba (39 59'57"W, 13¹2'19"S); CFBH 18797 (male), Fazendas Santo Onofre and Cana Brava, Maracás (approx. 40²5'23.58"W, 13²3'29.30"S); MHNJCH 1701 (male), near Fazendas Santo Onofre and Cana Brava, Maracás (40²6'26.23"W, 1321'59.10"S); MHNJCH 1698-1700 (males), Assentamento do Cumbe, Maracás (4027'38"W, 13²6'40"S); MZUESC 14890, 14893 (males), and 14891 (female), Companhia de Pesquisa de Recursos Minerais

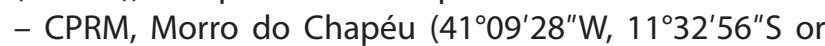
$\left.41^{\circ} 06^{\prime} 26^{\prime \prime} \mathrm{W}, 11^{\circ} 29^{\prime} 34^{\prime \prime} \mathrm{S}\right) ;$ MZUESC 15894 and 17503 (females), Praça Municipal, Potiraguá (3957'30"W, $15^{\circ} 37^{\prime} 07^{\prime \prime}$ S); and UFMG 4787 (male), Route Sebastião Laranjeiras-Candiba, Sebastião Laranjeiras (approx. $\left.42^{\circ} 56^{\prime} 21.34^{\prime \prime} \mathrm{W}, 14^{\circ} 33^{\prime} 13.74^{\prime \prime} \mathrm{S}\right)$.

\section{Diagnosis (based on neotype and referred specimens)}

Scinax $x$-signatus is a species of Scinax, as it shares three synapomorphies of this genus: webbing between toes I and II that does not extend beyond the subarticular tubercle of toe $\mathrm{I}$; origin of the $\mathrm{m}$. pectoralis abdominalis through well-defined tendons; and $\mathrm{m}$. pectoralis abdominalis overlapping m. obliquus externus (da Silva, 1998; Faivovich, 2002; Faivovich et al., 2005). A single synapomorphy is known for the $S$. ruber Clade: tadpoles with the vent tube above the margin of the lower fin (Faivovich, 2002; Faivovich et al., 2005). While tadpoles unequivocally associated to $S$. $x$-signatus remain unknown, this species was associated to the $S$. ruber Clade by having the unique combination of external vocal sac and presence of pectoral fold [internal vocal sac and pectoral fold absent in most species of the $S$. catharinae Clade; in few species where the vocal sac is external, the pectoral fold is absent (e.g., S. garibaldiae, S. rizibilis); otherwise, in the two cases where the pectoral fold is present, the vocal sac is internal (S. agilis and S. melanodactylus); J. Faivovich \& K. Araujo-Vieira, pers. obs.; see also Bokermann, 1964; Cruz \& Peixoto, 1982; Faivovich, 2002; Lourenço et al., 2014, 2019].

Scinax $x$-signatus can be differentiated from all other species of the S. ruber Clade by the combination of the 
following characters: (1) male SVL 34.5-38.4 mm, $n=13$; (2) snout rounded in dorsal view and profile; (3) pointed tubercles on lower jaw absent; (4) vocal sac subgular, weakly bilobate; (5) spicule-shaped papillary epidermal projections on the nuptial pads and pectoral region present in males; (6) pectoral glands present in males; (7) dorsal color pattern with large irregular dark blotches, commonly with dark X-shaped mark composed of one or two pairs of inverted parenthesis-like blotches; (8) hidden surfaces of thighs dark with irregular pale blotches, yellow in living specimens; (9) iris yellowish golden or bronze with a median black streak; (10) physiological chlorosis absent; and (11) advertisement call composed of a single, multipulsed note, 0.11-0.25 s duration, 6-14 pulses/note, 52-64 pulses/s.

\section{Comparisons with other species of Scinax ruber Clade}

The SVL in males of Scinax x-signatus (34.5-38.4 mm, $n=13$ ) distinguishes it from the larger species $S$. castroviejoi and S. eurydice (SVL males 44.0-52.0 mm; De la Riva, 1993; Bokermann, 1968), and from the smaller species S. altae, S. auratus, S. cabralensis, S. caldarum, S. cruentomma, S. danae, S. exiguus, S. fuscomarginatus, S. juncae, S. karenanneae, S. lindsayi, S. madeirae, S. maracaya, S. ruberoculatus, S. rupestris, S. staufferi, S. strussmannae, S. tymbamirim, S. villasboasi, and S. wandae (SVL males 15.7-29.0 mm; Lutz, 1968, 1973; Duellman, 1970, 1986; Pyburn \& Fouquette, 1971; Cardoso \& Sazima, 1980; Duellman \&Wiens, 1993; Pyburn, 1992, 1993; Drummond et al., 2007; Nunes \& Pombal, 2010, 2011; Nunes et al., 2012; Brusquetti et al., 2014; Araujo-Vieira et al., 2015; Ferrão et al., 2018a, b).

The snout rounded in dorsal view and profile differentiates Scinax $x$-signatus from S. alter, S. auratus, S. cretatus, S. crospedospilus, S. imbegue, S. juncae, and S. tymbamirim (sub-elliptical with a pointed tip in dorsal view and slightly acute in profile), S. fuscovarius (roundly acute in dorsal view and protruding in profile), S. caldarum, S. curicica, S. duartei, S. maracaya, S. rossaferesae, and S. tigrinus (sub-elliptical or subovoid in dorsal view and slightly acute in profile), S. squalirostris (pointed in dorsal view and acute in profile), and species of the S. rostratus group (elongate pointed in dorsal view and acute with or without a fleshy proboscis in profile). Furthermore, the absence of pointed tubercles on the lower jaw differentiates $S$. $x$-signatus from almost all species of the S. rostratus Group; exceptions are S. kennedyi and S. rostratus (e.g., Duellman, 1972a, 1973; Pyburn, 1973; Lescure \& Marty, 2000; Lima et al., 2005; this study).

The presence of a weakly bilobate subgular vocal sac in Scinax $x$-signatus distinguishes it from $S$. camposseabrai (bilobate subgular vocal sac; see also Caramaschi \& Cardoso, 2006: fig. 1) and from the remaining species of the S. ruber Clade with single subgular vocal sac; exceptions are S. acuminatus, S. dolloi, S. funereus, S. fuscovarius, S. hayii, S. karenanneae, S. montivagus, S. onca, S. oreites, S. pachycrus, S. perereca, S. ruberoculatus, and S. tsachila, that have a weakly bilobate subgular vocal sac (e.g., Cei, 1980; Duellman \& Wiens, 1993; Pyburn, 1993; Ferrão et al., 2017, 2018a; this study).
The presence of spicule-shaped papillary epidermal projections on the nuptial pad and pectoral region in males differentiates Scinax $x$-signatus from all other species of the $S$. ruber Clade, except for $S$. fuscovarius (see also Luna et al., 2018: fig. 10A, C). The presence of pectoral glands in males differentiates $S$. $x$-signatus from most species of the $S$. ruber Clade, except for $S$. funereus, S. fuscovarius, S. nasicus, S. onca, and S. similis, and species of the S. uruguayus Group (e.g., Müller \& Hellmich, 1936; Lutz, 1973; Cei, 1980; this study).

The dorsal pattern with large irregular dark blotches, commonly with dark X-shaped marks composed of one or two pairs of inverted parenthesis-like blotches, distinguishes Scinax x-signatus from S. altae, S. alter, S. auratus, S. boesemani, S. caldarum, S. cretatus, S. crospedospilus, S. curicica, S. cuspidatus, S. duartei, S. exiguus, S. fuscomarginatus, S. imbegue, S. juncae, S. madeirae, S. oreites, S. pachycrus, S. quinquefasciatus, S. ruber, S. squalirostris, S. staufferi, S. tsachila, S. tymbamirim, and S. villasboasi (variable number of dorsal and/or lateral stripes; e.g., Duellman, 1970; Lutz, 1973; Duellman \& Wiens, 1993; Pugliese et al., 2004; Nunes et al., 2012; Brusquetti et al., 2014; Ron et al., 2018; this study), and S. blairi, S. cabralensis, S. chiquitanus, S. danae, S. iquitorum, S. lindsayi, S. maracaya, and S. strussmannae (scattered or homogeneously distributed spots and/or irregular blotches; e.g., Fouquette \& Pyburn, 1972; Cardoso \& Sazima, 1980; De la Riva, 1990; Drummond et al., 2007; Ferrão et al., 2018b; this study).

The hidden surfaces of thighs dark colored with light irregular pale blotches, yellow in living specimens differentiate Scinax $x$-signatus from S. altae, S. auratus, S. baumgardneri, S. boesemani, S. cretatus, S. crospedospiIus, S. cruentomma, S. cuspidatus, S. danae, S. elaeochroa, S. exiguus, S. fuscomarginatus, S. ictericus, S. iquitorum, S. madeirae, S. manriquei, S. pachycrus, S. ruberoculatus, S. staufferi, S. strussmannae, S. squalirostris, S. tsachila, S. villasboasi, S. wandae, and species of the S. uruguayus Group (hidden surfaces of thighs uniform, light or dark colored; e.g., Rivero, 1961; Duellman, 1970, 1986; Lutz, 1973; De la Riva, 1990; Duellman \& Wiens, 1993; BarrioAmorós et al., 2004; Nunes \& Pombal, 2011; Brusquetti et al., 2014; Ferrão et al., 2018a, b; Ron et al., 2018; Baldo et al., 2019; this study), S. funereus, S. onca, and S. iquitorum (hidden surfaces of thighs with horizontal or irregular dark blotches; Duellman, 1971; Ferrão et al., 2017; Moravec et al., 2009; this study), and from species of the S. rostratus Group (hidden surfaces of thighs uniform light or marked with bold dark and light mottling or broad vertical bars; Duellman, 1972a, 1973; Henle, 1991; Lescure \& Marty, 2000; Lima et al., 2005; this study).

The yellowish golden or bronze iris, with a median black streak, distinguishes Scinax $x$-signatus from $S$. cruentomma (silvery bronze iris, with a median red streak; Duellman et al., 1972b), S. ruberoculatus (bicolored, reddish upper half and grey lower half; Ferrão et al., 2018a), and species of the S. uruguayus Group (bicolored, golden upper half and dark brown to black lower half; Baldo et al., 2019). The absence of physiological chlorosis in S. $x$-signatus distinguishes it from S. boesemani, S. caprar- 
ius, S. cruentomma, S. cuspidatus, S. elaeochroa, S. funereus, S. ictericus, S. iquitorum, S. karenanneae, S. manriquei, S. onca, S. strussmannae, and S. tsachila (present in these species; León, 1969; Lutz, 1973; Pyburn, 1993; La Marca, 2004; Moravec et al., 2009; Cole et al., 2013; Melo-Sampaio \& Souza, 2015; Ferrão et al., 2017, 2018b; Acosta-Galvis, 2018; Ron et al., 2018; Taboada et al., 2020).

The advertisement call composed of a single multipulsed short note (0.11-0.25 s), with 6-14 pulses/note, and pulse rate of 52-64 pulses/s differentiates Scinax $x$-signatus from $S$. castroviejoi and $S$. eurydice (two or three multipulsed notes; De la Riva, 1993; De la Riva et al., 1994; Pombal et al., 1995a; Magrini et al., 2011; Mângia et al., 2017), S. alter, S. curicica, and S. perereca (note duration 0.28-4.5 s and 21-152 pulses/note; Pombal et al., 1995a, b; Pugliese et al., 2004), S. cruentomma, S. fuscomarginatus, and $S$. strussmannae (17-90 pulses/note and 113-272 pulses/s; De la Riva et al., 1994; Duellman, 1972b; Brusquetti et al., 2014; Carvalho et al., 2015; Ferrão et al., 2018b), S. exiguus (23-90 pulses/note; Carvalho et al., 2017), S. madeirae (note duration 0.72-1.16 s and 104-145 pulses/s; Brusquetti et al., 2014), S. staufferi (100-130 pulses/s; León, 1969), S. wandae (note duration 0.44-0.69 s and 70-108 pulses/note; Pyburn \& Fouquette, 1971; Duellman, 1986; Pombal et al., 2011), and from some large species of the S. rostratus Group: S. boulengeri and S. proboscideus (80-230 pulses/s; León, 1969; Duellman, 1972a), S. jolyi (note duration $2.5 \mathrm{~s}$ and 180 pulses/note; Lescure \& Marty, 2000), S. kennedyi (note duration 0.66-2.9 s; Pyburn, 1973), and S. sugillatus (note duration 0.28-0.60 s and 110-140 pulses/s; Duellman, 1973).

\section{Description of the neotype}

Head as wide as long, HL $35.1 \%$ and HW 33.2\% of SVL (Fig. 2). Snout rounded in dorsal view and profile, with a low protuberance on the tip (Fig. 3A, B). Nostrils dorsolateral, elliptical, protruded; IND $39.7 \%$ of IOD. Canthus rostralis marked, convex. Loreal region slightly concave. Eyes large, protuberant, ED $94.7 \%$ of IOD and $92.3 \%$ of END. Pupil horizontal, subelliptical. Tympanum rounded, separated from eye by a distance almost half TD; TD $75.0 \%$ of ED. Tympanic annulus rounded, with the posterior upper portion hidden by the supratympanic fold. Supratympanic fold evident, from the posterior upper portion of the tympanum to the insertion of the forearm. Vocal sac subgular, weakly bilobate, externally evident by the loose skin, not occupying space between head and body, and ventrally not reaching the pectoral fold (Fig. 2B). Pectoral fold present, with pre- and postaxillar elements. Vocal slits present, nearly parallel to the mandible, originating laterally to the tongue and running towards the corner of the mouth. Tongue ovoid, free laterally and posteriorly, slightly notched posteriorly. Vomerine teeth in two slightly separated convex series, bearing five (right) and four (left) teeth. Choanae oval.

Axillary membrane absent. Upper arm more slender than forearm. A series of small, flat, ulnar tubercles on the forearm. Fingers short and slender, fringed (Fig. 3C). Relative finger length $\|<\| I I \approx V<I V$. Discs elliptical, wider than long, 3FD 59.2\% of TD; disc of Finger II smaller than others. Subarticular tubercles single, conical on fingers II and III; rounded and quadrangular on fingers IV and V. Supernumerary tubercles small, single, rounded. Inner metacarpal tubercle single, elliptical; outer metacarpal tubercle flat, nearly triangular, bilobate. Webbing absent between fingers II and III; basal between fingers III, IV, and V. Slightly thickened, light-colored nuptial pad, covering Metacarpal II dorsomedially, and ventrally extending from the base of inner metacarpal tubercle, obscuring its outer margin, to the subarticular tubercle (Fig. 4A, B). Glandular acini on inner margin of fingers II-III; on Finger II from the distal margin of nuptial pad to the disc. Spicule-shaped papillary epidermal projections on the nuptial pad, margins of fingers II-III (Fig. 4A, B), and dorsum of fingers II-V.

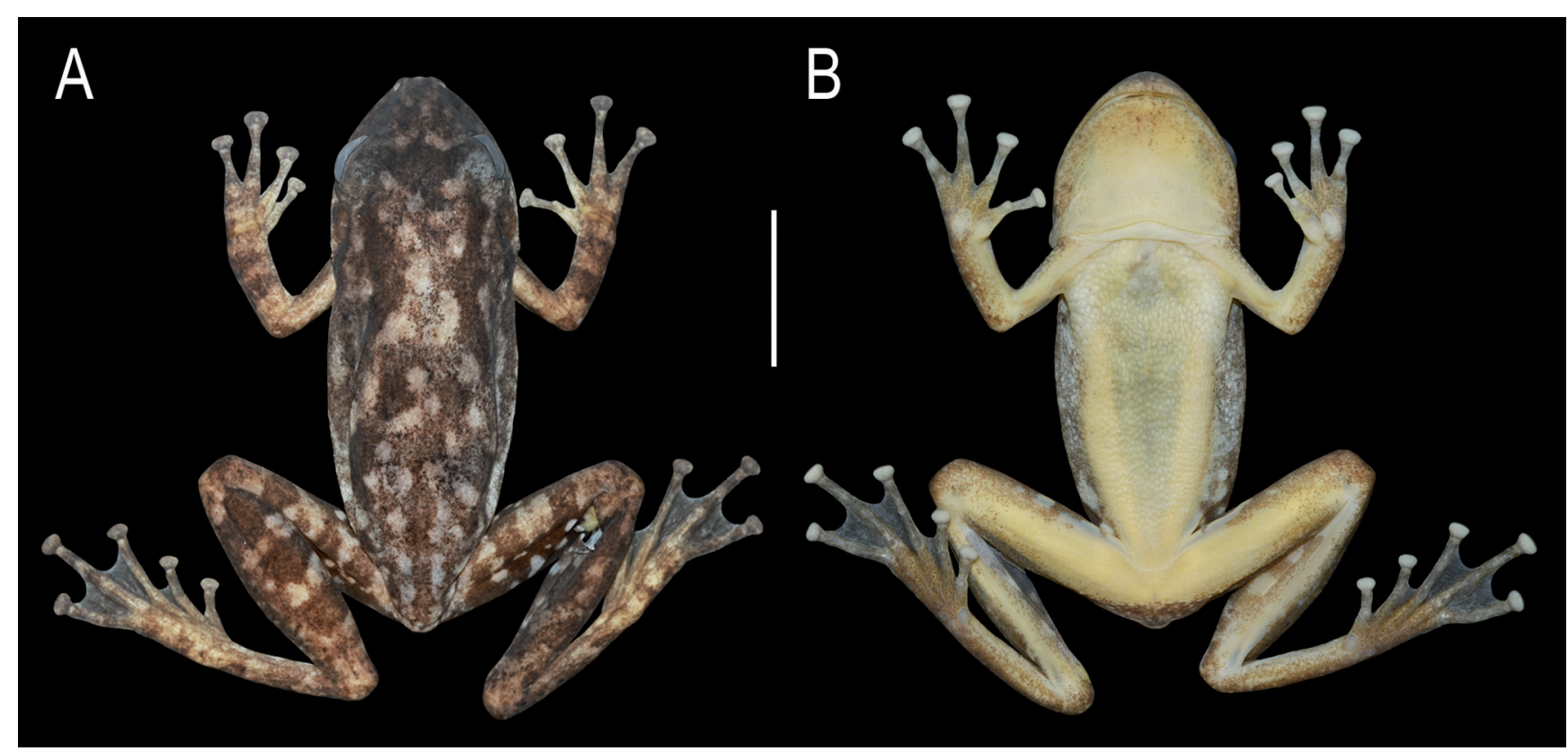

Figure 2. Neotype of Scinax x-signatus (CFBH 44688, male). (A) Dorsal view. (B) Ventral view. Scale bar $=10 \mathrm{~mm}$. 

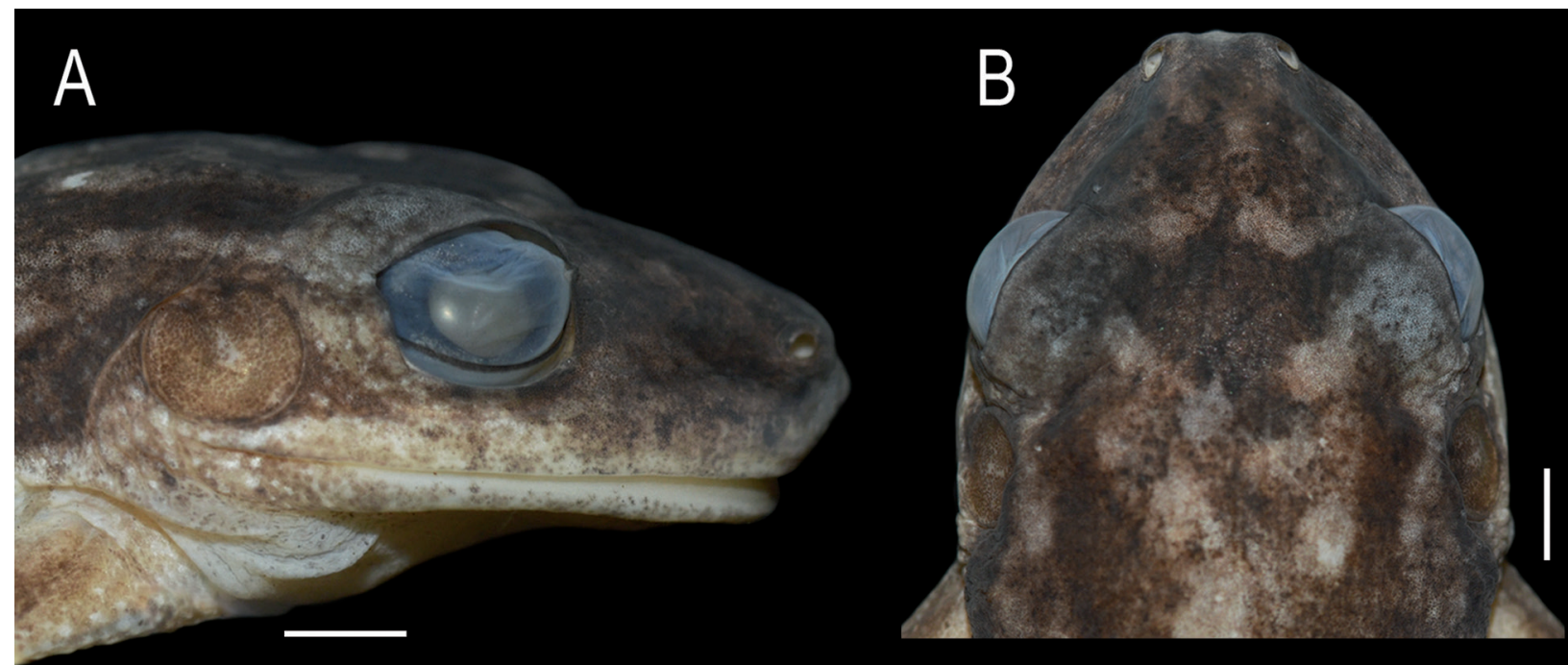

C

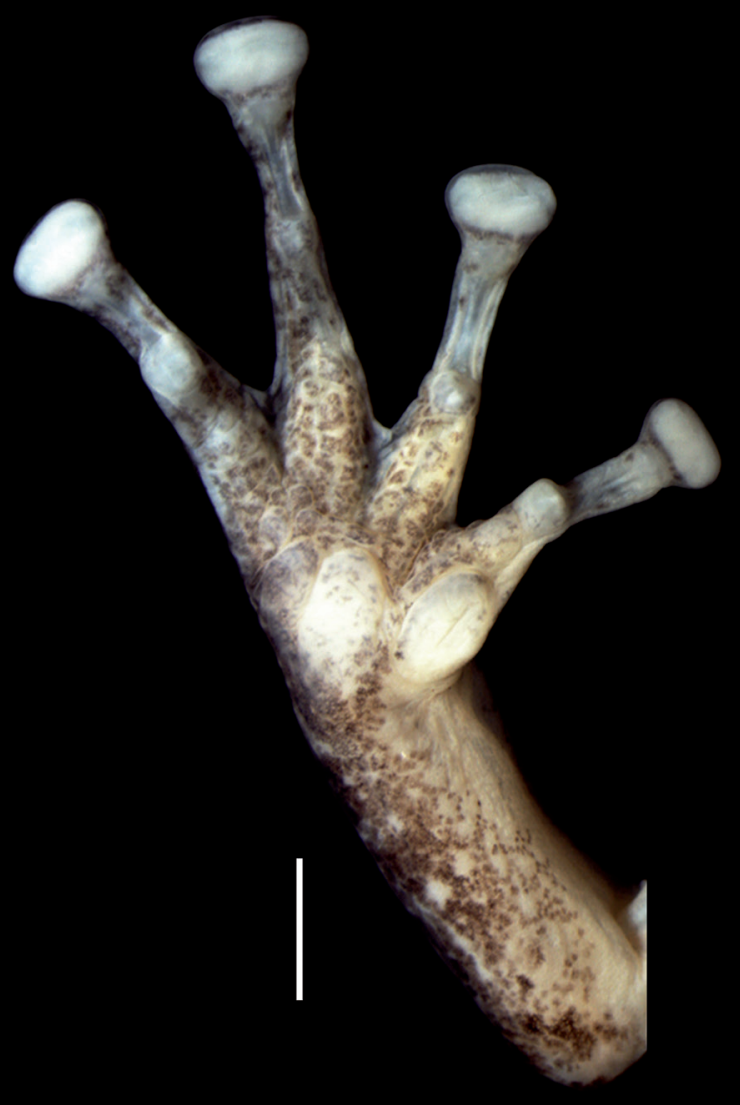

D

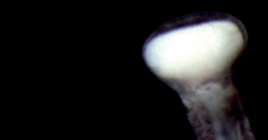

Figure 3. Neotype of Scinax x-signatus (CFBH 44688, male). (A) Head, profile. (B) Head, dorsal view. (C) Right hand, ventral view. (D) Right foot, ventral view. Scale bars $=2 \mathrm{~mm}$. 


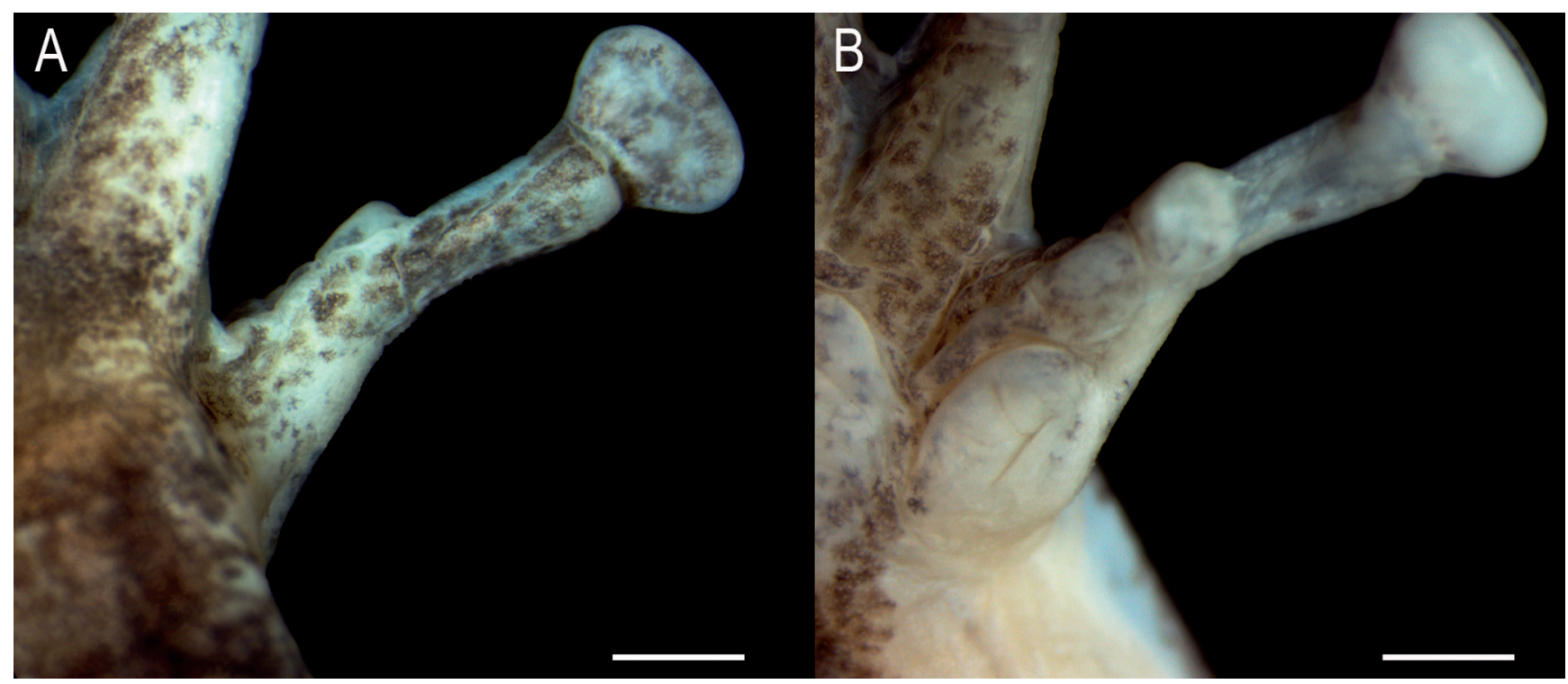

Figure 4. Neotype of Scinax x-signatus (CFBH 44688, male). Nuptial pad of the right hand. (A) Dorsal view. (B) Ventral view. Scale bars $=1 \mathrm{~mm}$.

Hindlimbs robust; TL $49.0 \%$ of SVL, FL $39.8 \%$ of SVL. Toes slender, fringed (Fig. 3D). Relative toe length $\mathrm{I}<\mathrm{Il}<\mathrm{III} \approx \mathrm{V}<\mathrm{IV}$. Discs elliptical, wider than long, slightly smaller than discs of fingers, 4TD $=3 F D$. Subarticular tubercles single, conical, rounded; supernumerary tubercles small, single, rounded. Inner metatarsal tubercle single, elliptical; outer metatarsal tubercle single, slightly marked, two thirds smaller than inner tubercle. Webbing formula I $2-2^{+}$|| $1^{1 / 4}-2^{+}$III $1-2^{1 / 3}$ IV $2^{+}-1 \mathrm{~V}$. Fringe on lateral margin of Toe $V$ extends along the margin of the sole by a poorly developed ridge that reaches the distal portion of the metatarsus. Ventrolateral margin of tarsus smooth; heel slightly granular.

Cloacal opening directed posteriorly at upper level of thighs. Skin on dorsum of head, upper eyelid, trunk, and limbs smooth, with scattered granules. Posterior corner of eyes, around tympanum and forearm insertion, supratympanic fold, and flanks granular. Vocal sac, hidden surfaces of limbs, and inguinal region smooth; other ventral surfaces and subcloacal area densely covered with rounded, flat granules. Pectoral region and inner margin of upper- and forelimbs with glandular acini, covered with spicule-shaped papillary epidermal projections.

Measurements (mm): SVL 36.7; HL 12.9; HW 12.2; IND 2.5; IOD 3.8; ED 3.6; END 3.9; TD 2.7; FL 14.6; TL 18.0; 3FD 1.6; 4TD 1.6.

Coloration in life: The description is based on the freshly euthanized specimen (Fig. 5). Dorsal color dark brown, with two pairs of large, irregular, black blotches on the suprascapular and sacral regions, and scattered, small, round or irregular, light blotches; interocular region with an inverted triangle-shaped, black marking (Fig. 5A). Upper lip light with diffuse brown blotches anteriorly, and a white stripe on the infraorbital region extending to posterior margin of the tympanum. Loreal region brown with small, irregular, black dots; dark brown canthal line. Post-orbital dark brown line from anterior corner of the eyes, upper margin of tympanum, to the middle of the flanks. Flanks light with irregular, dark brown blotches. Dorsal surfaces of discs, fingers, toes, forearms, and tarsus brownish gray with transverse, brown bars; upper arms uniform; shanks and thighs with large dark brown blotches. Toe webbing covered by brown melanophores. Iris grayish bronze with thin black reticulations, thin yellow halo bordering the pupil, and a median black streak.

Soles and palms light brown; glandular pectoral region yellowish white; other ventral areas creamy white, immaculate, but margins of gular region, around forearm insertion and knees, tarsus, and shanks finely spotted with brown (Fig. 5B). Inguinal region yellow, with irregular dark blotches. Hidden surfaces of thighs and shanks brown, with small to medium-size, rounded or irregular yellow blotches (Fig. 5C). White bones.

Coloration in preservative: Paler than in the fresh specimen. The coloration on the glandular pectoral region, inguinal region, and hidden surfaces of thighs and shanks faded to light beige or cream white.

\section{Variation}

See Table 1 for measurements of the available specimens. Vomerine teeth vary from 5 to 8 . In some individuals, the medial constriction of the vocal sac is barely evident externally. Snout rounded in dorsal view and profile, with or without a low protuberance on the tip. Toe webbing formula varies as follows: I $\left(2^{+}-2^{-}\right)-\left(2^{1 / 2}-2^{-}\right)$ II $\left(1^{1 / 2}-1\right)-\left(2^{1 / 2}-2^{-}\right)$III $\left(1^{1 / 2}-1\right)-\left(2^{1 / 2}-2\right)$ IV $\left(2^{+}-2^{-}\right)-\left(1^{+}-1\right) \mathrm{V}$.

Dorsal skin similar to that of neotype, with scattered or uniformly distributed granules. Ulnar and tarsal tubercles protuberant or inconspicuous. Three or four, low, rounded tubercles can be present next to the tibio-tarsal articulation; the distal one is elongated in some individuals.

In freshly euthanized specimens, dorsal color varies from beige or gray to dark brown, with large irregular brown to black blotches, and small white blotches (Fig. 6). In males, pectoral region light yellow and abdo- 

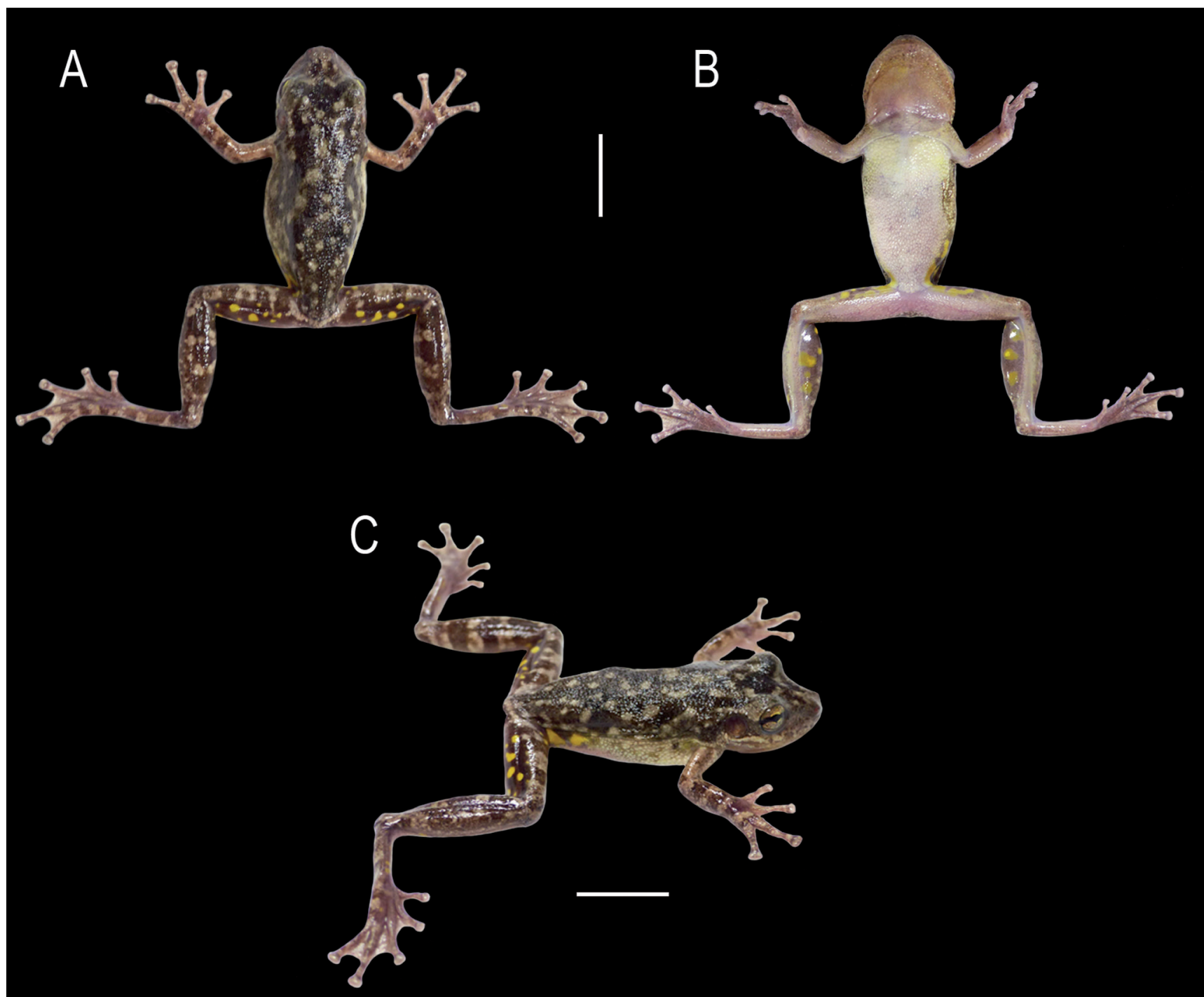

Figure 5. Neotype of Scinaxx-signatus (CFBH 44688, male). Freshly euthanized individual. (A) Dorsal view. (B) Ventral view. (C) Dorsolateral view. Scale bars $=10 \mathrm{~mm}$.

men yellowish beige; in females, cream white. Inguinal region light yellow or yellow, with irregular dark blotches; hidden surfaces of thighs, shanks, and tarsi brown to black, with small to large, rounded or irregular yellow blotches. Flanks light yellow or cream white; axillae yellow in some individuals. Iris yellowish golden or bronze, with many thin, dark reticulations, and a median black streak. In life, overall coloration similar to fleshly euthanized specimens. Still, dark and light tones are more intense and brighter, especially yellow coloration on inguinal region and hidden surfaces of hindlimbs (Fig. 7). Iris iridescent yellowish golden or bronze (Fig. 7A-E).

In preservative, dorsal pattern varies from light beige or light gray to dark brown, with large, irregular dark blotches, usually with X-shaped marks composed of one or two pairs of inverted parentheses-like blotches, with or without light blotches (Fig. 8). Small, dark brown, irregular blotches on the dorsum of all individuals. Interocular marking can be inverted triangle, T-shaped, or W-shaped, sometimes fragmented. Upper lip light with diffuse brown blotches, sometimes with a white infraorbital stripe that extends to the tympanum. Dark canthal line present in all specimens. Post-orbital line varies in extension, reaching posteriorly level of forearm insertion or middle of flanks. Dark blotches on flanks and inguinal region rounded or irregular. Small to large, rounded or irregular light blotches on hidden surfaces of hindlimbs. Ventral surfaces from cream white to light beige, finely or conspicuously covered with brown spots in some individuals. Dark coloration predominates on dorsum of specimen MHNJCH 1014 (Fig. 8L); however, this resulted from the fixation process in $10 \%$ formalin. In life, this specimen showed the X-shaped mark and other dorsal blotches common to the other specimens.

The occurrence of glandular tissue in the pectoral region has been considered a secondary sexually dimorphic character occurring in males (Lutz, 1973), and this is corroborated here (Fig. 9A). This is also the case of the spicule-shaped papillary epidermal projections on the nuptial pad (Fig. 9B, C), inner margin of upper- and forearms, and pectoral region. The glandular areas (acini) on the inner margins of upper- and forearms, and fingers II-III (excluding the nuptial pad) are absent in some specimens (e.g., MHNJCH 1014, 1698-1700); when present, spicule-shaped papillary epidermal projections also occur on these areas. Spicule-shaped projections can be 


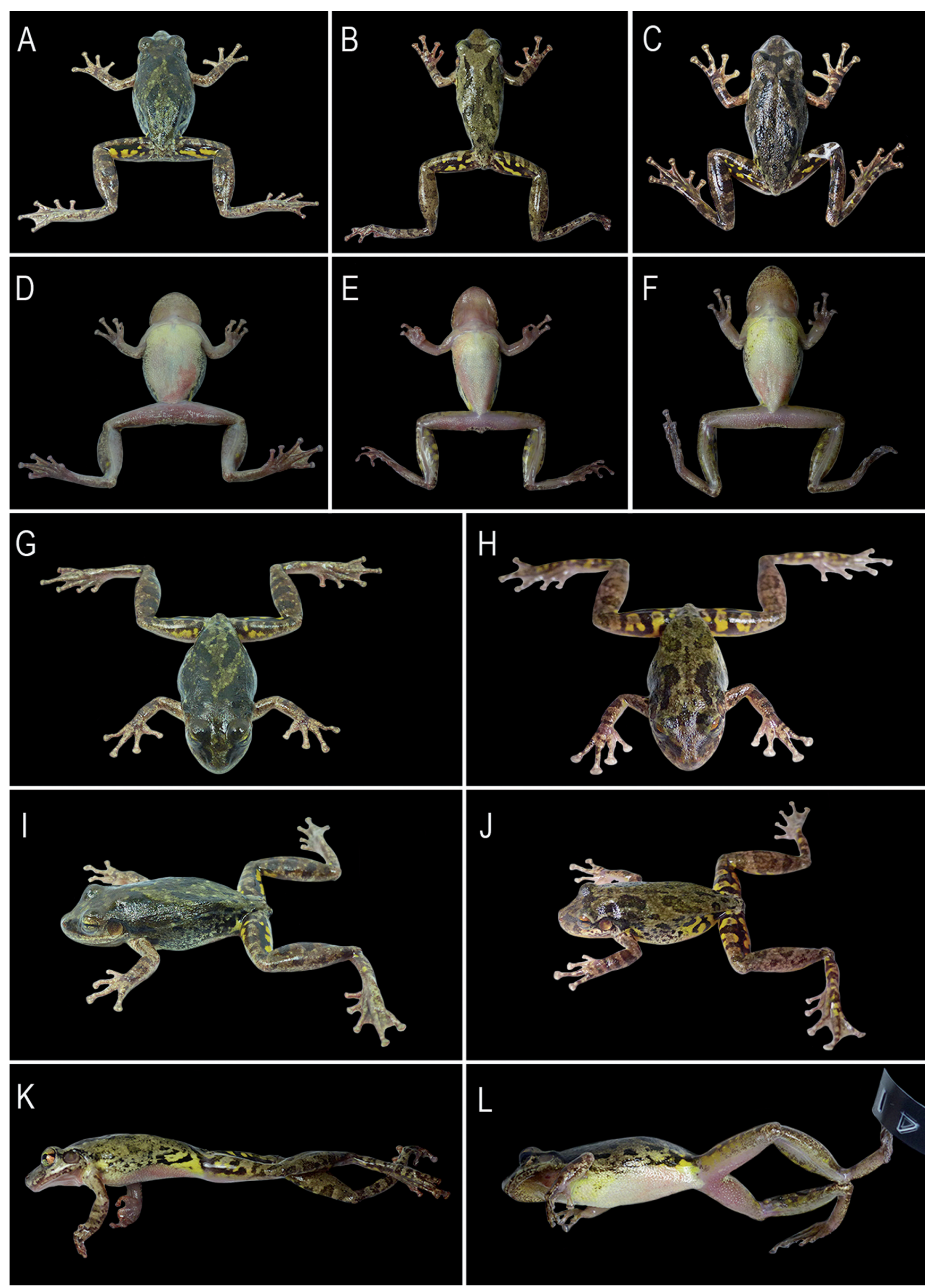

Figure 6. Variation in the color pattern of freshly euthanized specimens of Scinax x-signatus. (A), (D), (G), and (I) CFBH 44687 (male). (B), (E), and (K) MHNJCH 1701 (male). (C), (F), and (L) MHNJCH 1698 (male), (H) and (J) MZUESC 20683 (male). 
present, scattered, and apparently not associated to acini on fingers II-V in some individuals. Although our sample of females is small (three individuals), females tend to be larger than males (Table 1).

\section{Advertisement call}

The advertisement call of Scinax $x$-signatus consists of a single multipulsed note, emitted at a highly variable repetition rate (2-105 notes/minute; Table 2; Fig. 10A), which is likely affected by conspecific chorus density, since the longer intervals between notes (up to $25.3 \mathrm{~s}$; Table 2) were observed in the recording of the neotype, which was calling alone with no nearby conspecific. Notwithstanding, much longer intervals are the exception, and the notes are repeated at faster rates (29-105 notes/minute; Table 2 ), but never composing a stereotyped series.
Note duration is $0.11-0.25 \mathrm{~s}$ (Table 2; Fig. 10A-C); each note is composed of 6-14 pulses with modulating amplitude increasing from the first third, reaching the maximum amplitude around the middle of the note, and gradually decaying towards the last pulse (Fig. 10B, C). Pulse rate is $52-64$ pulses/s and pulse duration 0.013-0.018 s (Fig. 10B, C).

Calls have a broadband spectrum (BW90\% 2250-2799 Hz; Table 2; Fig. 10C). The power spectrum is usually biphasic, with two main emphasized frequency bands (Fig. 10C). The lower band (i.e., the low-frequency band) comprises most of the power of the spectrum, with the dominant frequency ranging between 904-1359 Hz (Fig. 10C), and also including part of the freq5\% (861-991 Hz; Table 2). The upper band (i.e., the high-frequency band) has less power than the first one, surrounding the freq95\% (3188-3704 Hz; Table 2), with

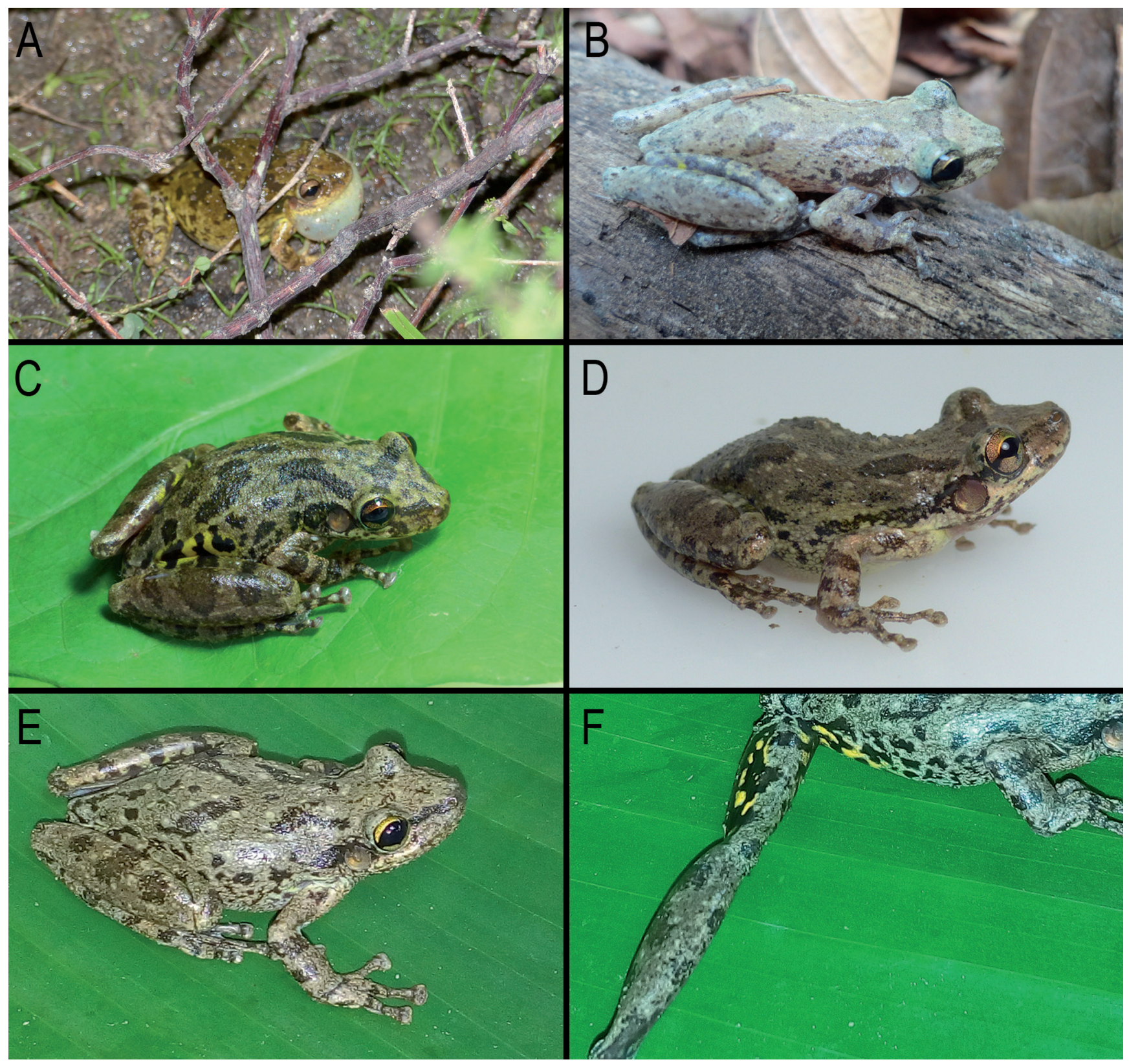

Figure 7. Living specimens of Scinaxx-signatus. (A) CFBH 44687 (male). (B) MZUESC 15894 (female). (C) MZUESC 20683 (male). (D) MHNJCH 1701 (male). (E-F) MZUESC 17503 (female). Notice the coloration in life in the flank, inguinal region, and posterior surface of thigh in (F). Photos B, E, and F courtesy of Carlos Augusto S. Costa. 

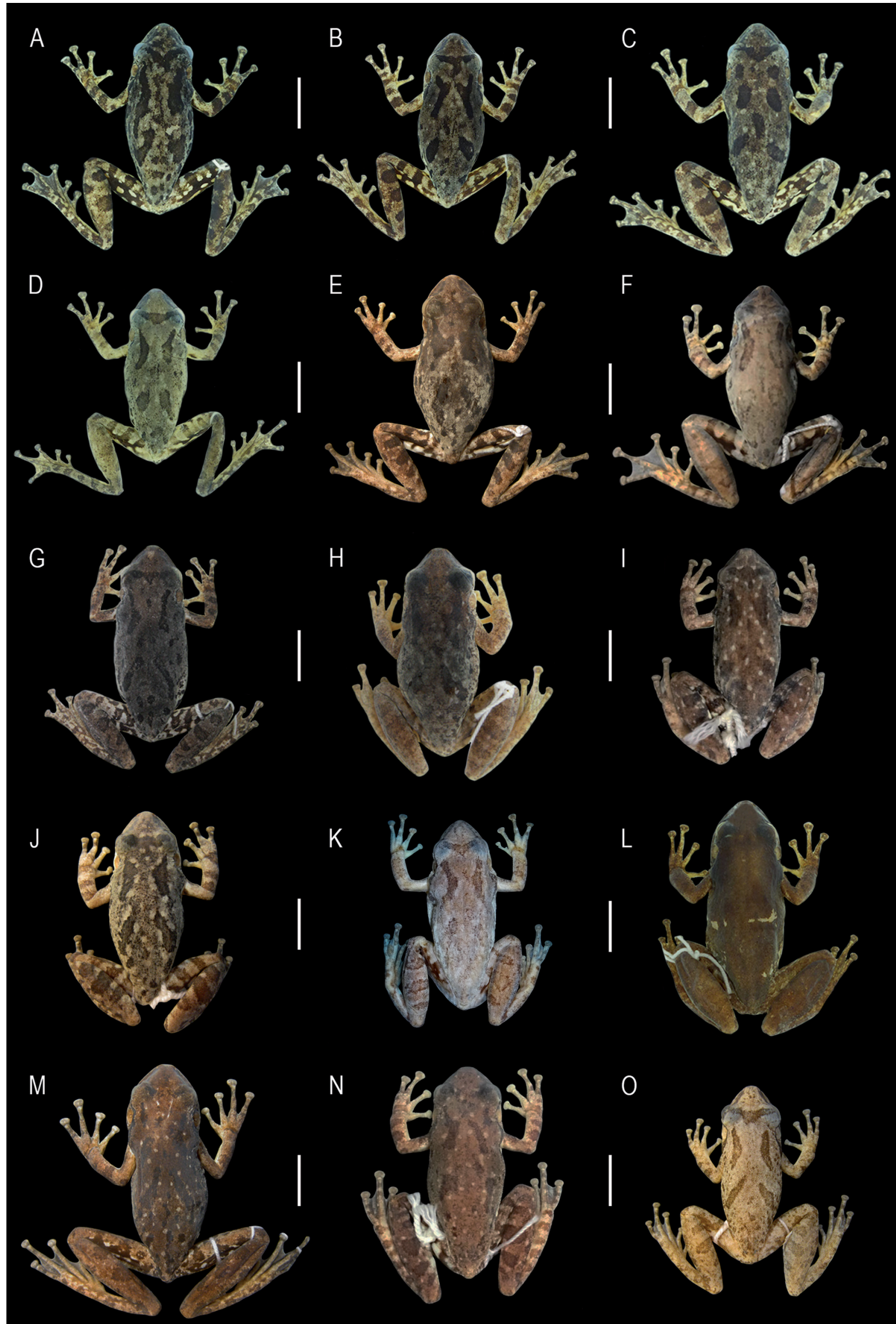

N

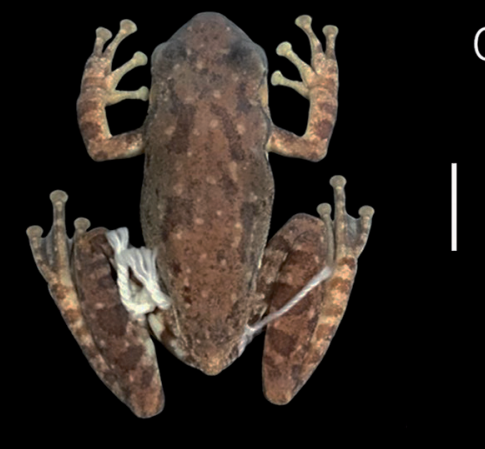

0

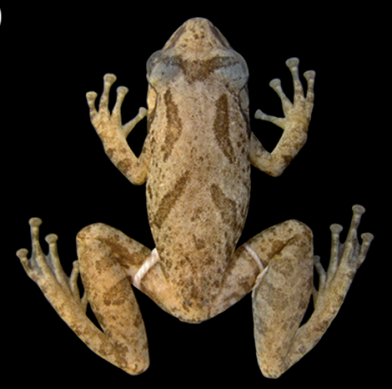

Figure 8. Variation in the dorsal color pattern of preserved Scinax x-signatus. (A) MHNJCH 1700 (SVL $36.9 \mathrm{~mm}$, male). (B) MHNJCH 1698 (SVL $35.0 \mathrm{~mm}$, male). (C) MHNJCH 1699 (SVL $37.8 \mathrm{~mm}$, male). (D) MHNJCH 1701 (SVL $35.0 \mathrm{~mm}$, male). (E) CFBH 44687 (SVL $37.2 \mathrm{~mm}$, male). (F) MZUESC 20683 (SVL $34.5 \mathrm{~mm}$, male). (G) UFMG 4787 (SVL 38.0 mm, male). (H) CFBH 18797 (SVL 37.0 mm, male). (I) MZUESC 14890 (SVL 35.5 mm, male). (J) MZUESC 14893 (SVL 37.1 mm, male). (K) CFBH 21071 (SVL $36.8 \mathrm{~mm}$, male). (L) MHNJCH 1014 (SVL $38.4 \mathrm{~mm}$, male). (M) MZUESC 17503 (SVL $44.7 \mathrm{~mm}$, female). (N) MZUESC 14891 (SVL $38.2 \mathrm{~mm}$, female). (0) MZUESC 15894 (SVL $32.9 \mathrm{~mm}$, female). Scale bars $=10 \mathrm{~mm}$. 

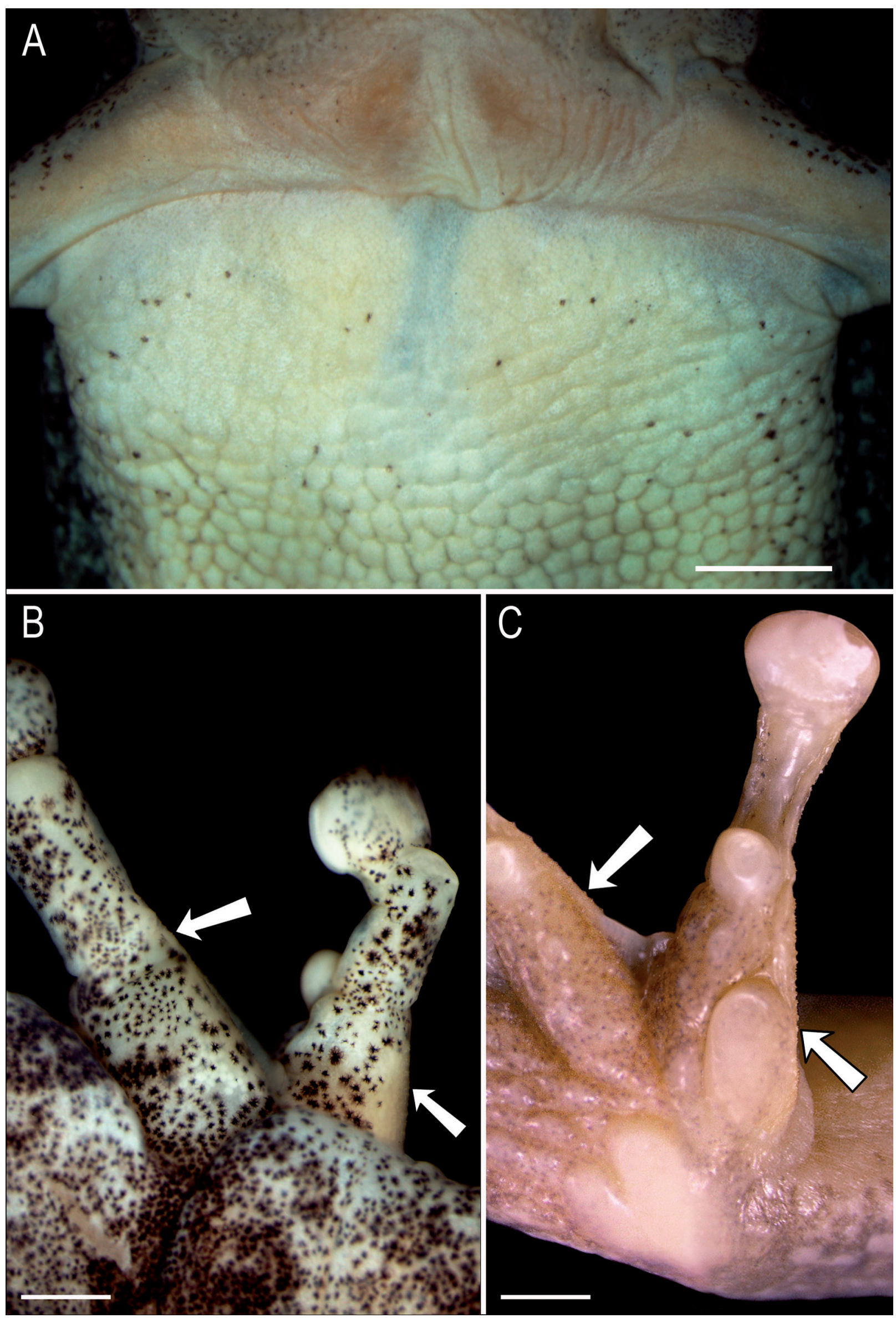

Figure 9. Pectoral glands and spicule-shaped papillary epidermal projections in males of Scinax X-signatus. (A) Pectoral glands of CFBH 44687; notice the whitish cream glandular area (acini) in the pectoral region. Right hand of MZUESC 14893 and MHNJCH 1014, respectively. (B) Dorsal view. (C) Ventral view. White arrows indicate the spicule-shaped projections on nuptial pads and inner margin of Finger III. Scale bars $=1 \mathrm{~mm}$ (upper) and $2 \mathrm{~mm}$ (lower). 


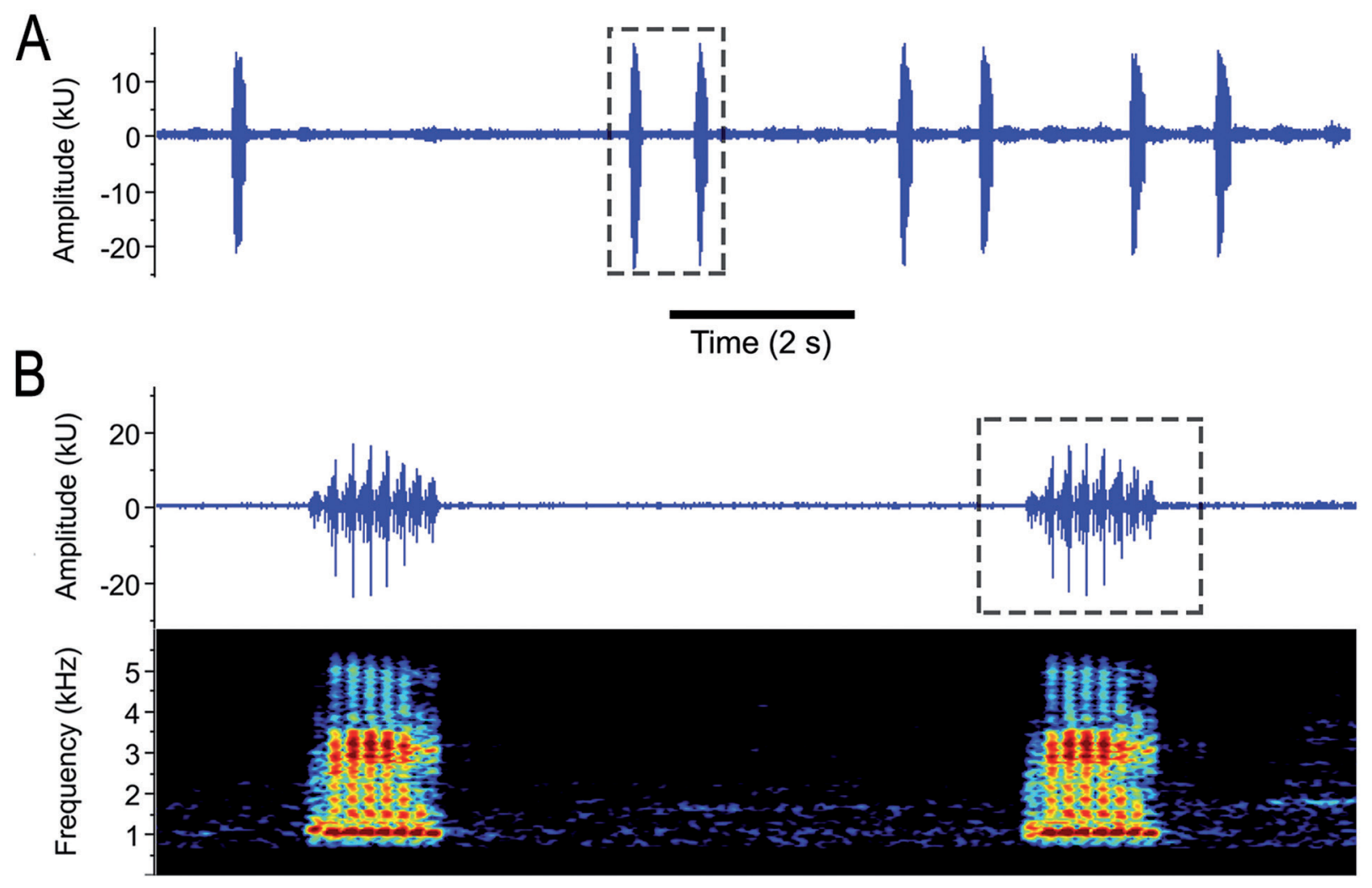

Time (1 s)

C
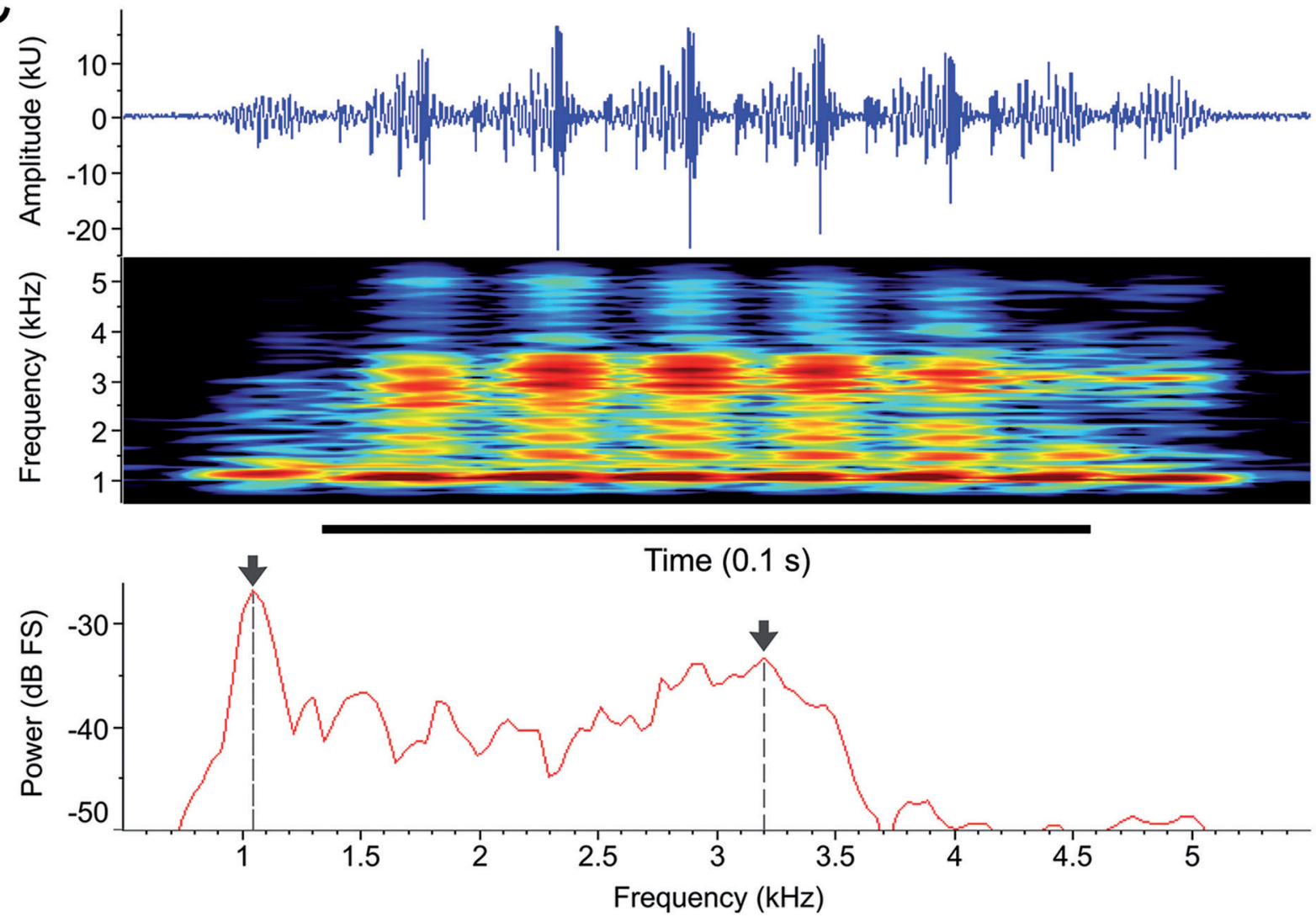

Figure 10. Advertisement call of the neotype of Scinax x-signatus (CFBH 44688, male). (A) Waveform showing seven notes; the dashed square highlights two notes showed in (B). (B) Waveform (on top) and spectrogram (on bottom) showing two consecutive notes; dashed square highlights the note showed in (C). (C) Waveform (on top), spectrogram (in the middle), and power spectrum (on bottom) of a single note; notice the amplitude modulation in the intermediate pulses, with four crescent peaks; the arrows and dashed vertical lines in the power spectrum highlights the dominant frequency in the low-frequency band (on the left) and the peak frequency of the high-frequency band (on the right). 
its peak frequency between $2885-3618 \mathrm{~Hz}$ (Fig. 10C). Between the two power spectrum bands, there is a low-power "valley" (or gap) around 2.0-2.5 kHz (Fig. 10C). The dominant frequency does not alternate between the lower and upper bands, remaining in the lower band.

\section{Notes on calling site and calling behavior}

Males of Scinax $x$-signatus call near lentic water bodies, either natural or artificial (such as pools and tanks). They usually call from the ground, either uncovered or hidden among the vegetation. Less often, they call perched at low heights (below $1.5 \mathrm{~m}$; rarely above that height) on the vegetation inside or at the margins of water bodies. Other species of Scinax found calling syntopically with S. $x$-signatus are Scinax sp. aff. hayii, S. auratus, S. eurydice, and S. pachycrus. Scinax $x$-signatus seems to tolerate some degree of light and sound disturbance; as we recorded the neotype inside the University Campus, with plenty of artificial light and crowd voices as background noise.

\section{Phylogenetic analysis}

The two most parsimonious trees (length 468) recovered all specimens considered in the literature as Scinax $x$-signatus closely related with the neotype and our referred specimens (100\% jackknife; Fig. 11). These include specimens from Bahia, Ceará, and Pernambuco (NE Brazil) and Amapá (N Brazil), and from French Guiana and Martinique (Fig. 12). The selected fragment of the mitochondrial ribosomal gene 16S rRNA showed uncorrected pairwise distances of $0.2-1.7 \%$ among the 28 individuals of $S$. $x$-signatus (Table 3 ). The maximum value $(1.7 \%)$ is between specimens from Kourou and Ile Royale (French Guiana), and those from Ubajara (Ceará, NE Brazil), Fernando de Noronha, and Sanharó (Pernambuco, NE Brazil); the geographic distances between these points are approx. 1,700 km (see distances between points 8-9 and 14-15 in Fig. 12).

Scinax $x$-signatus is moderately supported (85\% jackknife) as sister taxon of Scinax sp. (as S. $x$-signatus "Scinax_64" in Vacher et al., 2020) from Parque Nacional Cavernas do Peruaçu, Januária, N Minas Gerais, Brazil. Uncorrected pairwise distances between $S$. $x$-signatus and Scinax sp. are 6.9-10.2\%, with a sequence divergence of $8.0 \%$ between one specimen of $S$. $x$-signatus (UFMG 4787) from Sebastião Laranjeiras (Bahia, NE Brazil) only distant approx. $170 \mathrm{~km}$ ENE from the locality of this candidate species in N Minas Gerais (see Fig. 12). The voucher specimen of Scinax sp. (MTJ0578) was not available for morphological study, and therefore we are not aware of any diagnostic characters for this candidate species. The

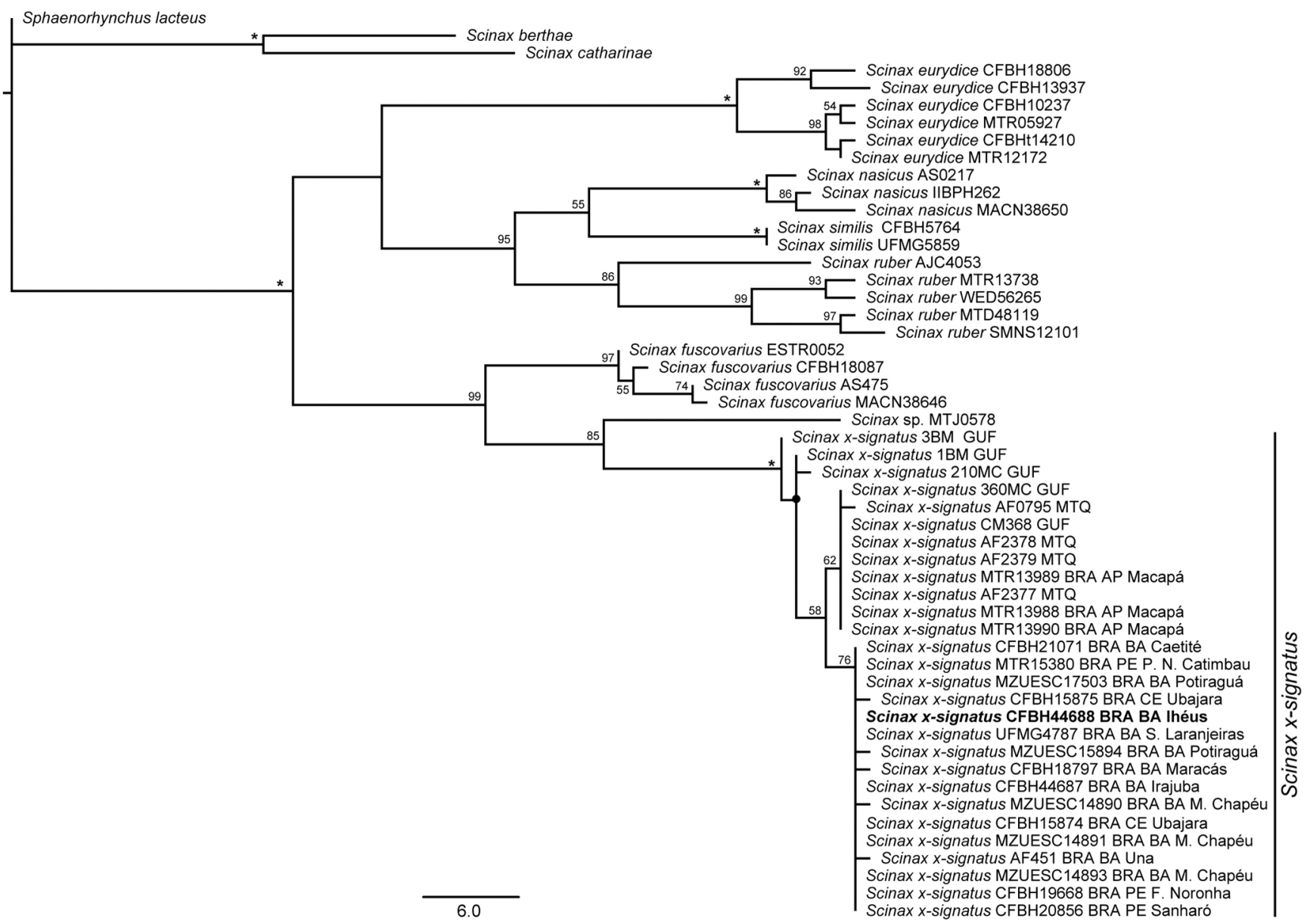

Figure 11. One of the two most parsimonious trees (length 468 steps) obtained from the analysis of the 165 rRNA mitochondrial gene in TNT with gaps as fifth state. Values above or below nodes are jackknife support values. Nodes without values indicate $<50 \%$ jackknife support; black dot indicates a node that collapses in the strict consensus; an asterisk $\left.{ }^{*}\right)$ indicates groups with $100 \%$ jackknife support. 


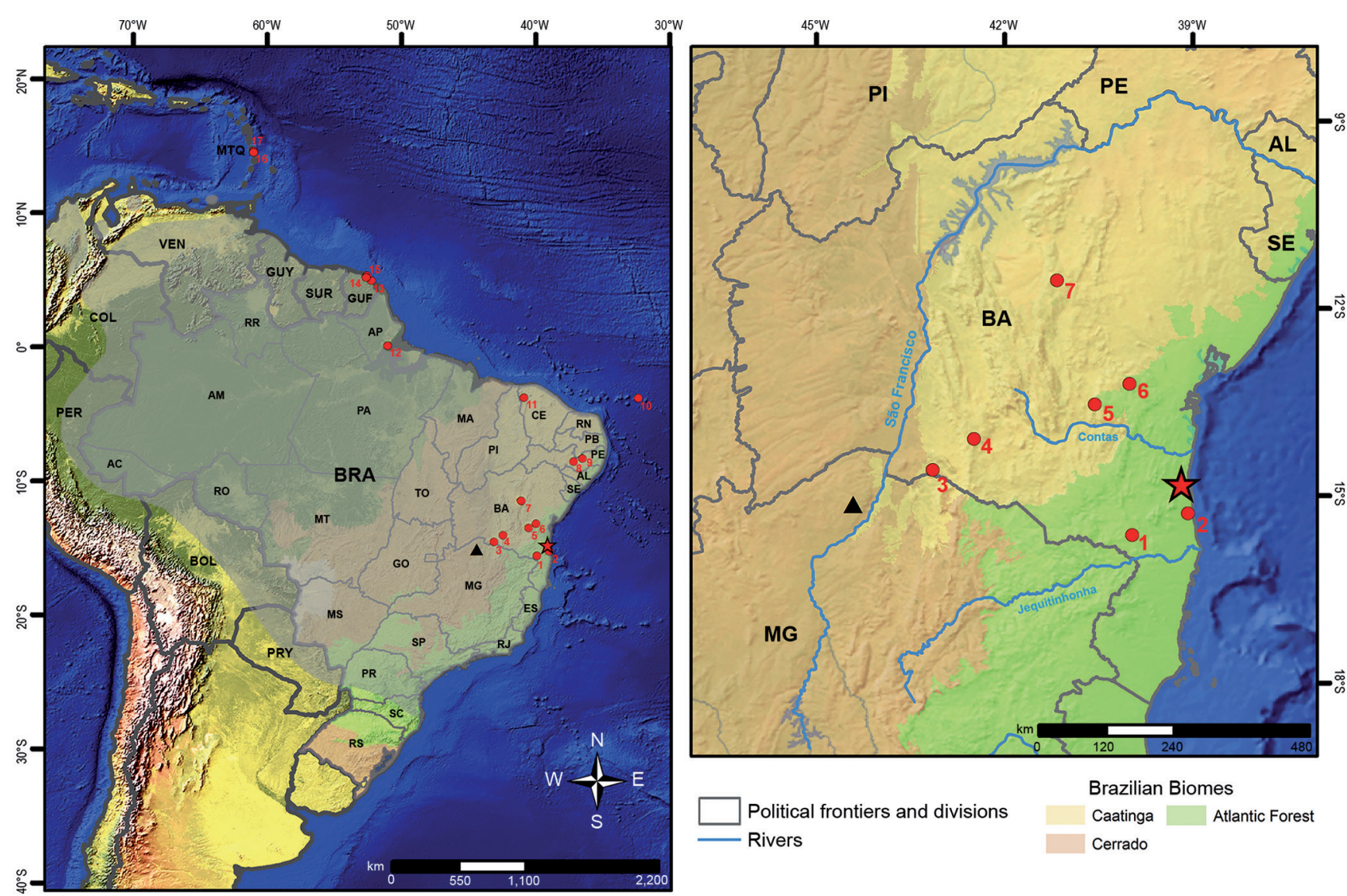

Figure 12. Distribution map of Scinax x-signatus showing localities of specimens with sequences of the 16S rRNA mitochondrial gene included in this study. Gray shadow on the left highlights the putative distribution of S. $x$-signatus taken from IUCN Red List of Threatened Species (Rodrigues et al., 2010). Note that although it includes Paraguay, Bolivia, and Peru, we are not aware of published records assigned to $S$. $x$-signatus from these countries. The dashed square on the left highlights the area on the right showing the distribution of $S . x$-signatus in the State of Bahia, Brazil. Black triangle: Januária (Scinax sp.). Red star: Ilhéus (neotype of S. $x$-signatus). Red dots. 1 = Potiraguá. $2=$ Una. $3=$ Sebastião Laranjeiras. $4=$ Caetité. $5=$ Maracás. $6=$ Irajuba. $7=$ Morro do Chapéu. $8=$ Parque Nacional do Catimbau. $9=$ Sanharó. $10=$ Fernando de Noronha. $11=$ Ubajara. $12=$ Macapá. $13=$ Montravel. $14=$ Korou. $15=$ lle Royale. $16=$ Diamant. $17=$ Unknown. Abbreviations. Countries: BRA = Brazil. BOL = Bolivia. COL = Colombia. GUF $=$ French Guiana. GUY $=$ Guyana. PER $=$ Peru. PRY $=$ Paraguay. SUR $=$ Surinam. VEN $=$ Venezuela. Brazilian states: $A C=$ Acre. $A L=$ Alagoas. $A M=$ Amazonas. $A P=$ Amapá. $B A=$ Bahia. $C E=$ Ceará. $E S=E$ spírito Santo. $G 0=G$ oiás. $M A=M a r a n h a ̃ o . ~ M G=M i n a s$ Gerais. MS = Mato Grosso do Sul. MT = Mato Grosso. PA = Pará. PB = Paraíba. PE = Pernambuco. PI = Piauí. PR = Paraná. RJ = Rio de Janeiro. RN = Rio Grande do Norte. $\mathrm{RO}=$ Rondônia. $\mathrm{RR}=$ Roraima. $\mathrm{RS}=$ Rio Grande do Sul. $\mathrm{SC}=$ Santa Catarina. $\mathrm{SE}=$ Sergipe. $\mathrm{SP}=$ São Paulo. $\mathrm{TO}=$ Tocantins.

clade S. $x$-signatus + Scinax sp. is well-supported $(99 \%$ jackknife) as sister taxon of $S$. fuscovarius, followed by a poorly supported clade ( $<50 \%$ jackknife) composed of S. eurydice, S. nasicus, S. ruber, and S. similis.

\section{DISCUSSION}

Scinax $x$-signatus has been considered to occur in Colombia, Venezuela, Guyana, Suriname, French Guiana, and extensive areas in Brazil, including also oceanic islands such as Fernando de Noronha (introduced), Guadeloupe, La Désirade, Margarita, Marie Galante, and Martinique (e.g., Lescure \& Marty, 2000; Juncá, 2006; Henderson \& Powell, 2009; Ugueto \& Rivas-Fuenmayor, 2010; Ouboter \& Jairam, 2012; Cole et al., 2013; Novaes \& Zina, 2016; Barrio-Amorós et al., 2019). As reviewed earlier in this paper, several authors expressed concerns regarding the taxonomy of this species and the possibility that the name had been applied to several different species. Our designation of a neotype, and the analysis of
DNA sequences allows to conclude that S. $x$-signatus occurs at least in Northeastern and Northern Brazil, French Guiana, and the Islands of Fernando de Noronha (Brazil) and Martinique, as previously reported (e.g., Fouquet et al., 2007a, b; Lyra et al., 2016; Novaes \& Zina, 2016; Vacher et al., 2020; see Figs. 11, 12). However, our analysis lacks samples from Colombia, Venezuela, Suriname, Guyana, and many northeastern Brazilian states where several populations have been assigned to $S$. $x$-signatus. Our characterization of the neotype specimen and other referred specimens from some localities in the State of Bahia, Brazil, should be seen only as a partial characterization of this species. A more thorough study is now necessary, to understand its geographic variation along its extensive distribution.

The combination of several adult morphological and advertisement call characters differentiates Scinax $x$-signatus from the remaining 74 described species of the S. ruber Clade (see the Diagnosis section). However, two sexually dimorphic morphological characters present in males deserve comments, the pectoral glands, and the 


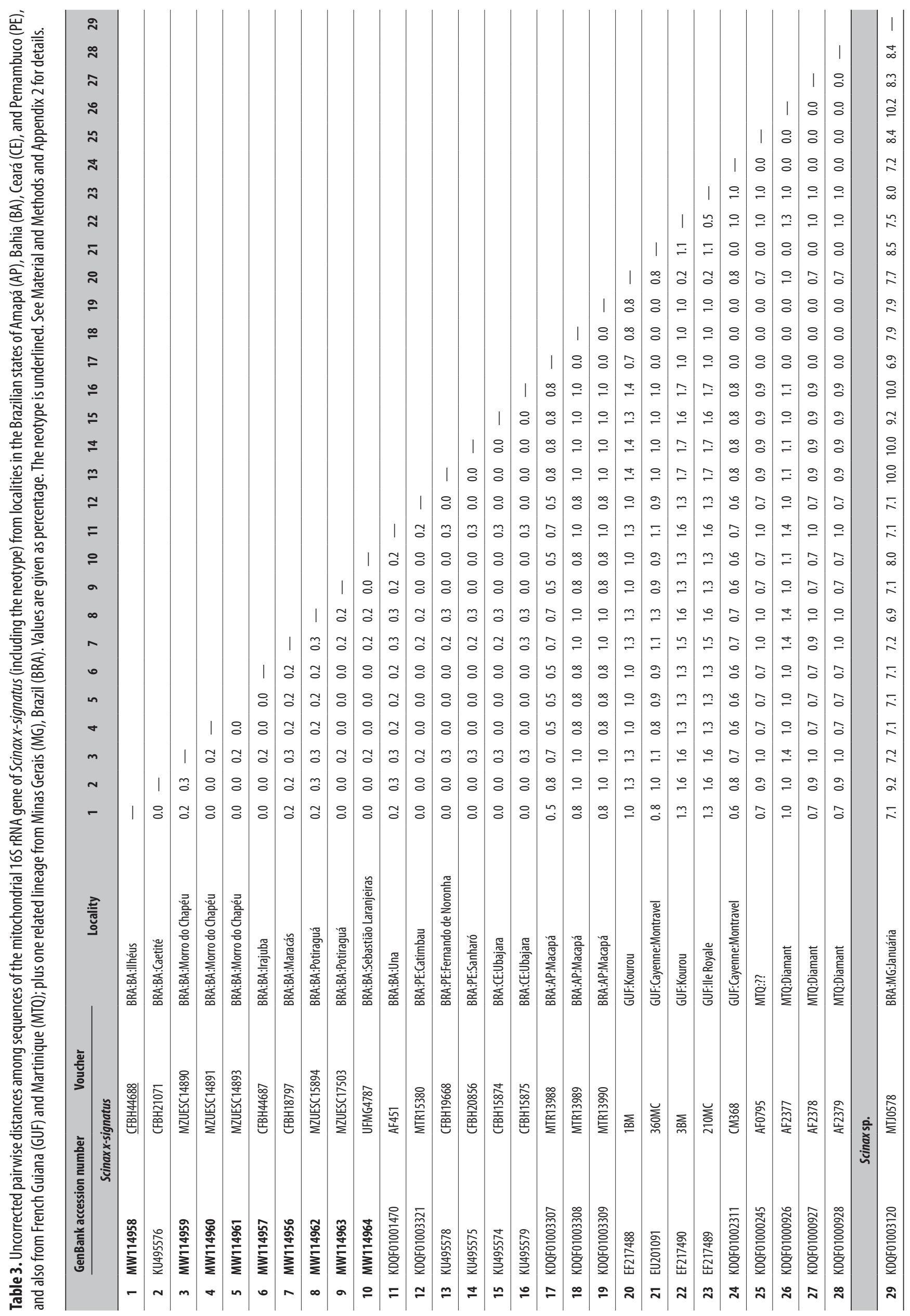


spicule-shaped papillary epidermal projections on the nuptial pad, inner margin of upper- and forearms, and pectoral region.

The pectoral glands of Scinax $x$-signatus (Fig. 9A), also present in S. funereus, S. fuscovarius, S. nasicus, S. onca, S. ruber, S. similis, and species of the S. uruguayus Group are evident externally by the presence of pale yellow, closely packed acini. These structures already have been described in S. fuscovarius, S. nasicus, and specimens assigned to $S$. $x$-signatus as "pectoral plaques" (Müller \& Hellmich, 1936; Lutz, 1973; Cei, 1980). We did not observe pectoral glands in females of S. fuscovarius, S. nasicus, and S. $x$-signatus, corroborating that they are sexually dimorphic characters.

A white, slightly thickened area on the pectoral region was observed in males of some species of the Scinax ruber Clade (e.g., S. eurydice, S. haddadorum, and S. pachycrus; Araujo-Vieira et al., 2016; this study). However, we did not observe the presence of packed acini in this region with high magnification, and therefore considered that these species lack pectoral glands. Histological studies are necessary to corroborate our observations. Otherwise, glandular acini in the pectoral region were reported for S. goya (the S. catharinae Clade; Andrade et al., 2018). These acini seem to be scattered throughout this region and likely not form a delimited area; it is unclear if these acini are sexually dimorphic in S. goya, since Andrade et al. (2018) did not mention them as absent in females.

Spicule-shaped papillary epidermal projections on nuptial pads were first described for Scinax fuscovarius by Luna et al. (2018), who find it similar to those previously described for the pipids Xenopus epitropicalis and X. tropicalis (Dolder, 1976; Evans et al., 2015). Our observations on several species of the $S$. ruber Clade showed the presence of these projections only on the nuptial pads of S. fuscovarius and S. x-signatus (see Fig. 9B, C; observations only missing for S. baumgardneri, S. blairi, S. castroviejoi, S. karenanneae, S. lindsayi, S. ruberoculatus, S. sateremawe, and S. strussmannae). These spicule-shaped projections are also present on the inner margins of upper- and forearms and fingers II-III, and in the pectoral region, always associated with glandular acini, but they might also be present on dorsum and outer margins of fingers II-V, where they are apparently not associated with acini. This distribution on the body suggests that further research is necessary to understand if these spicules represent sexually dimorphic characters that cover different parts including the nuptial pad, in which case they should not be considered as an intrinsic morphology of this structure (i.e., one of the many morphologies of papillary epidermal projections of the nuptial pad recognized by Luna et al., 2018).

The advertisement call parameters of Scinax $x$-signatus (note duration, dominant frequency, pulse duration, number of pulses/note, and pulse rate; see Table 2) from our recordings and those produced by Novaes \& Zina (2016) mostly overlap the values from recordings from Venezuela (Rivero, 1969; Tárano, 2010). Rivero (1969) attributed two different calls to $S$. $x$-signatus with dif- ferent pulse rate: 40 and 80 pulses/s. The spectrograms from the call with pulse rate of 40 pulses/s (Rivero, 1969: figs. 2,6 ) is similar to those of $S$. $x$-signatus described here (Fig. 10), whereas those from the call with pulse rate of 80 pulses/s are more similar to calls attributed to $S$. ruber by Rivero (1969; compare fig. 1 and fig. 3), as also noticed by De la Riva et al. (1994) and Novaes \& Zina (2016). Our call values for $S$. $x$-signatus overlap, in part, with those provided by Sichieri et al. (2019: fig. 2) for specimens from Bahia (e.g., note duration $0.10-0.34$ vs. $0.11-0.25 \mathrm{~s}$ in this study, number of pulses 5-27 vs. 6-14, pulses rate 32-90 vs. 52-64 pulses/s, and dominant frequency 1034-3790 vs. $904-1359 \mathrm{~Hz}$ ). Otherwise, the advertisement call of S. $x$-signatus reported by Freitas \& Toledo (2020: fig. 2E, table 1$)$ is different from those reported here in note duration (0.13-2.43 vs. $0.11-0.25 \mathrm{~s}$ in this study), number of pulses (5-104 vs. 6-14 pulses in this study), and dominant frequency $(950-4050$ vs. $904-1359 \mathrm{~Hz}$ in this study). These differences likely result from calls of different species that were analyzed under the name $S$. $x$-signatus, as also suggested by Freitas \& Toledo (2020: 9).

The advertisement call of Scinax $x$-signatus is similar to that of $S$. fuscovarius, in that both produce low frequency calls, with similar pulse structure, note duration, number of pulses per note, and pulse rate, and there are no obvious differences between the advertisement calls of these species (Pombal et al., 1995b; Bevier et al., 2008; Novaes \& Zina, 2016; this study). These species also share the presence of pectoral glands and spicule-shaped epidermal projections in males, as mentioned above.

The designation and description of a neotype for Scinax $x$-signatus, including information on advertisement calls and $16 \mathrm{~S}$ sequences, should make feasible the reevaluation of all previous records assigned to this species throughout its extensive distribution (e.g., Heyer et al., 1990; Gorzula \& Señaris, 1999; Lescure \& Marty, 2000; Izecksohn \& Carvalho-e-Silva, 2001; Juncá, 2006; Henderson \& Powell, 2009; Silva et al., 2010; Tárano, 2010; Ugueto \& Rivas-Fuenmayor, 2010; Ouboter \& Jairam, 2012; Cole et al., 2013; Nogueira et al., 2015; Barrio-Amorós et al., 2019; Dubeux et al., 2020; Señaris \& Rojas-Runjaic, 2020). In this sense, we showed that S. $x$-signatus is distinguishable from species such as $S$. eurydice, S. granulatus, S. nasicus, S. similis, and S. ruber, with which it had been confused throughout its distribution. Furthermore, cryptic or simply still unrecognized species previously associated with $S$. $x$-signatus could be diagnosed and described in future studies, as for example the candidate species Scinax sp. from N Minas Gerais, Brazil (Vacher et al., 2020).

\section{AUTHORS' CONTRIBUTIONS}

Katyuscia Araujo-Vieira and Julián Faivovich conceived and designed the study, carried out the sequencing, analyzed the data, wrote the original draft, revised and edited the final document, prepared figures and/or tables. José P. Pombal Jr. and Ulisses Caramaschi analyzed the data and revised the original draft. Gabriel Novaes-e- 
Fagundes collected specimens, recorded calls analyzed the data, revised the original draft, and prepared figures. Victor G.D. Orrico collected specimens, analyzed the data, and revised the original draft.

\section{ACKNOWLEDGMENTS}

We are grateful to Célio F.B. Haddad and Nadya Pupin $(\mathrm{CFBH})$, Guarino R. Colli and Reuber Brandão (CHUNB), Daniel Loebmann (CHFURG), Linda Trueb and William E. Duellman (KU), Santiago J. Nenda (MACN), Manoela Cardoso (MNRJ), Juliana Zina (MHNJCH), Antônio Argôlo (MZUESC), Hussam Zaher and Taran Grant (MZUSP), Jonathan A. Campbell (UTA), Júlio Moura-Leite (MHNCI), and Paulo C.A. Garcia (UFMG) for access to collections, institutional specimen loans, and lab assistance. We also thank Délio Baêta, Nadya Pupin, and Pedro Taucce (Rio Claro), Mark-Oliver Rödel and Frank Tillack (Berlin), Frank Glaw and Michael Franzen (Munich), Jörn Köhler (Darmstaadt), and Miguel Trefaut Rodrigues and Taran Grant (São Paulo) for information and comments. We also thank Carlos A.S. Costa, Cinthia A. Brasileiro, Deivson Fraga, Felipe C.B. Rosa, Felipe S.F. Leite, Jamille Freitas, João G.R. Giovanelli, Michael Cardoso, Tales Barbosa, and Tuliana O. Brunes for field assistance, Juvenal C. Silva Jr. for allowed access to his laboratory facilities, and Felipe S.F. Leite (UFV) for tissue loans. Mariana L. Lyra was of great help with lab procedures. Diego Baldo and José A. Langone read the manuscript and provided useful comments. K. Araujo-Vieira and J. Faivovich thank Fundação de Amparo à Pesquisa do Estado de São Paulo, Brazil (FAPESP procs. \#2013/50741-7, \#2014/50342-8, and \#2018/15425-0) and Agencia Nacional de Promoción Científica y Tecnológica, Argentina (ANPCyT, 820/2015). J.P. Pombal Jr. thanks the Conselho Nacional de Desenvolvimento Científico e Tecnológico, Brazil (CNPq) and Fundação Carlos Chagas Filho de Amparo à Pesquisa do Estado do Rio de Janeiro, Brazil. V.G.D. Orrico and G. Novaes-e-Fagundes thank the scholarships from CNPq (grant \#310467/2017-9) and Fundação de Amparo à Pesquisa do Estado da Bahia, Brazil (FAPESB; \#BOL0420/2019).

\section{REFERENCES}

Acosta-Galvis, A.R. 2018. Una nueva rana de huesos verdes del género Scinax (Anura: Hylidae) asociada a los bosques subandinos de la cuenca del río Magdalena, Colombia. Biota Colombiana, 19 (Supp. 1): 131-159.

Adler, K. 1981. Editor's note. In: Adler, K. (Ed.). Herpetology of Brazil (facsimilar reprint). Lawrence, Society for the Study of Amphibians and Reptiles, p. V-VII.

Andrade, S.P.; Santos, D.L.; Rocha, C.F.; Pombal Jr., J.P. \& Vaz-Silva, W. 2018. A new species of the Ololygon catharinae species group (Anura: Hylidae) from the Cerrado biome, State of Goiás, Central Brazil. Zootaxa, 4425(2): 283-303.

Araujo-Vieira, K.; Brandão, R.A. \& Faria, D.C.C. 2015. A new species of RockDwelling Scinax Wagler (Anura: Hylidae) from Chapada dos Veadeiros, Central Brazil. Zootaxa, 3915: 052-066.
Araujo-Vieira, K.; Valdujo, P.H. \& Faivovich, J. 2016. A new species of Scinax Wagler (Anura: Hylidae) from Mato Grosso, Brazil. Zootaxa, 4061(1): 261-273.

Baldo, D.; Araujo-Vieira, K.; Cardozo, D.; Borteiro, C.; Leal, F.; Pereyra, M.0, Kolenc, F.; Lyra, M.L.; Garcia, P.C.A.; Haddad, C.F.B. \& Faivovich, J. 2019. A review of the elusive bicolored iris Snouted treefrogs (Anura: Hylidae: Scinax uruguayus group). PLoS One, 14(9): e0222131.

Barrio-Amorós, C.L. 1998. Sistemática y biogeografía de los anfibios (Amphibia) de Venezuela. Acta Biologica Venezuelica, 18: 1-93.

Barrio-Amorós, C.L.; Brewer-Carías, C. \& Fuentes-Ramos, 0. 2011. Aproximación preliminar a la herpetocenosis de un bosque pluvial en la sección occidental de la Sierra de Lema, Guyana Venezolana. Revista de Ecología Latinoamericana, 16(1): 1-46.

Barrio-Amorós, C.L.; Orellana, A. \& Chacón, A. 2004. A new species of Scinax (Anura: Hylidae) from the Andes of Venezuela. Journal of Herpetology, 38(1): 105-112.

Barrio-Amorós, C.L.; Rojas-Runjaic, F.J.M. \& Señaris, J.C. 2019. Catalogue of the amphibians of Venezuela: Illustrated and annotated species list, distribution, and conservation. Amphibian \& Reptile Conservation, 13(1): 1-198.

Baumann, F. 1912. Brasilianische Batrachier des Berner Naturhistorischen Museums nebst Untersuchenugen über die geographische Verbreitung der Batrachier in Brasilien. Zoologische Jahrbücher. Abteilung für Systematik, 33: 87-172.

Berg, C. 1896. Batracios Argentinos. Enumeración sistemática, sinonímica y bibliográfica de los batracios de la República Argentina (con un cuadro sinóptico de clasificación). Anales del Museo Nacional de Historia Natural de Buenos Aires, 5: 147-226.

Bevier, C.R.; Gomes, F.R. \& Navas, C.A. 2008. Variation in call structure and calling behavior in treefrogs of the genus Scinax. South American Journal of Herpetology, 3(3): 196-206.

Bioacoustics Research Program. 2019. Raven Pro: Interactive Sound Analysis Software. Version 1.6. Computer Software. The Cornell La of Ornithology, Ithaca. Available: http://www.birds.cornel.edu/raven.

Bock, W.J. \& Shear, C.R. 1972. A staining method for gross dissection of vertebrate muscles. Anatomischer Anzeiger, 130(1): 222-227.

Bokermann, W.C.A. 1964. Dos nuevas especies de Hyla de Minas Gerais y notas sobre Hyla alvarengai (Amphibia, Salientia, Hylidae). Neotropica, 10(32): 67-76.

Bokermann, W.C.A. 1966. Lista anotada das localidades tipo de anfibios brasileiros. São Paulo, Impresso pelo Serviço de Documentação, RUSP. 183p.

Bokermann, W.C.A. 1968. Three new Hyla from the Plateau of Maracás, central Bahia, Brazil. Journal of Herpetology, 1: 25-31.

Bokermann, W.C.A. 1969. Notas sobre "Hyla aurata" Wied, 1824 (Anura, Hylidae). Revista Brasileira de Biologia, 29(2): 159-162.

Bokermann, W.C.A. \& Sazima, I. 1973. Anfíbios da Serra do Cipó, Minas Gerais, Brasil. 1: Duas espécies novas de Hyla (Anura, Hylidae). Revista Brasileira de Biologia, 33(3): 521-528.

Boulenger, G.A. 1882. Catalogue of the Batrachia Salientia s. Ecaudata in the collection of the British Museum. 2.ed. London, British Museum. 256p.

Brusquetti, F.; Jansen, M.; Barrio-Amorós, C.; Segalla, M. \& Haddad, C.F.B. 2014. Taxonomic review of Scinax fuscomarginatus (Lutz, 1925) and related species (Anura; Hylidae). Zoological Journal of the Linnean Society, 171(4): 783-821.

Burmeister, C.H.C. 1856. Erläuterungen zur Fauna Brasiliens, enthaltend Abbildungen und ausführliche Beschreibungen neuer oder ungenügend bekannter Thier-Arten. Berlin, G. Reimer.

Caramaschi,U.\& Cardoso, M.C.S. 2006. Taxonomic status of Hyla camposseabrai Bokermann, 1968 (Anura: Hylidae). Journal of Herpetology, 40(4): 549-552. 
Cardoso, A.J. \& Sazima, I. 1980. Nova espécie de Hyla do sudeste brasileiro (Amphibia, Anura, Hylidae). Revista Brasileira de Biologia, 40(1): 75-79.

Carvalho, T.R.; Teixeira, B.F.; Duellman, W.E. \& Giaretta, A.A. 2015. Scinax cruentommus (Anura: Hylidae) in the upper Rio Negro drainage, Amazonas state, Brazil, with the redescription of its advertisement call. Phyllomedusa: Journal of Herpetology, 14(2): 139-146.

Carvalho, T.R.D.; Azarak, P.; Bang, D.; Duellman, W. \& Giaretta, A. 2017. A reassessment of the vocalization and distribution of Scinax exiguus (Duellman, 1986) (Anura: Hylidae) in the Amazonian savanna of Roraima, northern Brazil, with the description of its aggressive call. Neotropical Biodiversity, 3(1): 196-202.

Cei, J.M. 1980. Amphibians of Argentina. Monitore Zoologico Italiano, Nuova Serie, Monographia, ixii + 609p.

Charif, R.A.; Waack, A.M. \& Strickman, L.M. 2010. Raven Pro 1.4 User's Manual. Cornell Lab of Ornithology, Ithaca, NY, 2010.

Cochran, D.M. 1952. Two brazilian frogs: Hyla werneri, n. nom. and Hyla similis, n. sp. Journal of the Washington Academy of Sciences, 42(2): 50-53.

Cochran, D.M. 1955. Frogs of Southeastern Brazil. United States National Museum Bulletin, 206: 1-423.

Cochran, D.M. \& Goin, C.J. 1970. Frogs of Colombia. United States National Museum Bulletin, 288: 1-655.

Cole, C.J.; Townsend, C.R.; Reynolds, R.P.; MacCulloch, R.D. \& Lathrop, A. 2013. Amphibians and reptiles of Guyana, South America: illustrated keys, annotated species accounts, and a biogeographic synopsis. Proceedings of the Biological Society of Washington, 125(4): 317-578.

Conte, C.E.; Araujo-Vieira, K.; Crivellari, L.B. \& Berneck, B.v.M. 2016. A new species of Scinax Wagler (Anura: Hylidae) from Paraná, Southern Brazil. Zootaxa, 4193(2): 245-265.

Cope, E.D. 1862. Catalogues of the reptiles obtained during the explorations of the Parana, Paraguay, Vermejo and Uruguay Rivers, by Capt. Thos. J. Page, U.S. N.; and of those procured by Lieut. N. Michler, U.S. Top. Eng., Commander of the expedition conducting the survey of the Atrato River. Proceedings of the Academy of Natural Sciences of Philadelphia, 14: 346-359.

Cope, E.D. 1870 "1869". Seventh contribution to the herpetology of tropical America. Proceedings of the American Philosophical Society, 11(81): 147-169.

Cope, E.D. 1874. On some Batrachia and Nematognathi brought from the upper Amazon by Prof. Orton. Proceedings of the Academy of Natural Sciences of Philadelphia, 26: 120-137.

Cruz, C.D. \& Peixoto, 0.L. 1982. Uma nova espécie de Hyla do Estado do Espírito Santo, Brasil (Amphibia, Anura, Hylidae). Revista Brasileira de Biologia, 42(4): 721-724.

Darst, C.R. \& Cannatella, D.C. 2004. Novel relationships among hyloid frogs inferred from 125 and 165 mitochondrial DNA sequences. Molecular Phylogenetics and Evolution, 31(2): 462-475.

Daudin, F.M. 1802 "An. XI". Histoire Naturelle des Rainettes, des Grenouilles et des Crapauds. Levrault, Paris. 108p.

De la Riva, I. 1990. Una especie nueva de Ololygon (Anura: Hylidae) procedente de Bolivia. Revista Española de Herpetología, 4: 81-86.

De la Riva, I. 1993. A new species of Scinax (Anura, Hylidae) from Argentina and Bolivia. Journal of Herpetology, 27: 41-46.

De La Riva, I.; Márquez, R. \& Bosch, J. 1994. Advertisement calls of Bolivian species of Scinax (Amphibia, Anura, Hylidae). Bijdragen tot de Dierkunden, 64(2): 75-85.

Dolder, H. 1976. Ultrastructure et formation des crochets sexuels chez 'Xenopus.' Revue Suisse de Zoologie, 82: 716-718.

Drummond, L.0.; Baêta, D. \& Pires, M.R.S. 2007. A new species of Scinax (Anura, Hylidae) of the S. ruber clade from Minas Gerais, Brazil. Zootaxa, 1612(1): 45-63.
Dubeux, M.J.M.; Nascimento, F.A.C.; Lima, L.R.F.; Magalhães, M.; da Silva, I.R.S.; Gonçalves, U.; Almeida, J.P.F.A.; Correia, L.L.; Garda, A.A.; Mesquita, D.0.; Rossa-Feres, D.C. \& Mott, T. 2020. Morphological characterization and taxonomic key of tadpoles (Amphibia: Anura) from the northern region of the Atlantic Forest. Biota Neotropica, 20(2): 1-24.

Duellman, W.E. 1970. The hylid frogs of Middle America. Monograph of the Museum of Natural History, The University of Kansas, 1: 1-753.

Duellman, W.E. 1971. A taxonomic review of South American hylid frogs, genus Phrynohyas. Occasional Papers of the Museum of Natural History, University of Kansas, 4: 1-21.

Duellman, W.E. 1972a. South American Frogs of the Hyla rostrata group (Amphibia, Anura, Hylidae). Zoologische Mededelingen, 47(14): 177-192.

Duellman, W.E. 1972b. A New Species of Hyla from Amazonian Ecuador. Copeia, 1972: 265-271.

Duellman, W.E. 1973. Descriptions of new hylid frogs from Colombia and Ecuador. Herpetologica, 29: 219-227.

Duellman, W.E. 1977. Liste der rezenten Amphibien und Reptilien. Hylidae, Centrolenidae, Pseudidae. Das Tierreich, 95: 1-225.

Duellman, W.E. 1986. Two new species of Ololygon (Anura: Hylidae) from the Venezuelan Guyana. Copeia, 1986: 864-870.

Duellman, W.E. \& Wiens, J.J. 1992. The status of the Hylid frog genus Ololygon and the recognition of Scinax Wagler, 1830. Occasional Papers of the Museum of Natural History, University of Kansas, 151: 1-23.

Duellman, W.E. \& Wiens, J.J. 1993. Hylid frogs of the genus Scinax Wagler, 1830, in Amazonian Ecuador and Peru. Occasional Papers of the Museum of Natural History, University of Kansas, 153: 1-57.

Duellman, W.E.; Marion, A.B. \& Hedges, S.B. 2016. Phylogenetics, classification, and biogeography of the treefrogs (Amphibia: Anura: Arboranae). Zootaxa, 4104(1): 1-109.

Duméril, A.M.C. \& Bibron, G. 1841. Erpétologie Générale ou Histoire Naturelle Compléte des Reptiles. Tome 8. Comprenant l'Histoire Générale des Batraciens, et la description des cinquante-duex generes et des cent soixante-trois espéces des duex premiers sous-ordres: Les péromèles qui n'ont pas de members, et les anoures qui sont privés de la queue. Librairie Encyclopédique de Roret, Paris.

Evans, B.J.; Carter, T.F.; Greenbaum, E.; Gvoždík, V.; Kelley, D.B.; McLaughlin, P.J.; Pauwels, 0.S.G.; Portik, D.M.; Stanley, E.L.; Tinsley, R.C.; Tobias, M.L. \& Blackburn, D.C. 2015. Genetics, morphology, advertisement calls, and historical records distinguish six new polyploid species of African Clawed Frog (Xenopus, Pipidae) from West and Central Africa. PLoS One, 10(12): e0142823: 1-51.

Fabrezi, M. \& Alberch, P. 1996. The carpal elements of anurans. Herpetologica, 52: $188-204$.

Faivovich, J. 2002. A cladistic analysis of Scinax (Anura: Hylidae). Cladistics, 18(4): 367-393.

Faivovich, J.; Haddad, C.F.B.; Garcia, P.C.A.; Frost, D.R.; Campbell, J.A. \& Wheeler, W.C. 2005. Systematic review of the frog family Hylidae, with special reference to Hylinae: phylogenetic analysis and taxonomic revision. Bulletin of the American Museum of Natural History, 294: 1-240.

Faivovich, J.; Pereyra, M.0; Luna, M.C.; Hertz, A.; Blotto, B.; Vásquez-Almazán, C.R.; McCranie, J.R.; Sanchez-Ramirez, D.; Baêta, D.; Araujo-Vieira, K.; Köhler, G.; Kubicki, B.; Campbell, J.A.; Frost, D.R. \& Haddad, C.F.B. 2018. The monophyly and relationships of several genera of Hylinae (Anura: Hylidae: Hylinae) with comments on recent taxonomic changes in hylids. South American Journal of Herpetology, 13(1): 1-32.

Farris, J.S.; Albert, V.A.; Källersjo, M.; Lipscomb, D. \& Kluge, A.G. 1996. Parsimony jackknifing outperforms neighbour-joining. Cladistics, 12(2): 99-124.

Ferrão, M.; Fraga, R.; Moravec, J.; Kaefer, I.L. \& Lima, A.P. 2018a. A new species of Amazonian snouted treefrog (Hylidae: Scinax) with description of a 
novel species-habitat association for an aquatic breeding frog. PeerJ, 6: e4321.

Ferrão, M.; Moravec, J.; Kaefer, I.L.; Fraga, R. \& Lima, A.P. 2018b. New species of Scinax (Anura: Hylidae) with red-striped eyes from Brazilian Amazonia. Journal of Herpetology, 52(4): 473-486.

Ferrão, M.; Moravec, J.; Fraga, R.; Almeida, A.P.; Kaefer, I.L. \& Lima, A.P. 2017. A new species of Scinax from the Purus-Madeira interfluve, Brazilian Amazonia (Anura, Hylidae). ZooKeys, 706: 137-162.

Fouquet, A.;Vences, M.;Salducci, M.-D.; Meyer, A.; Marty, C.; Blanc, M. \& Gilles, A. 2007a. Revealing cryptic diversity using molecular phylogenetics and phylogeography in frogs of the Scinax ruber and Rhinella margaritifera species groups. Molecular Phylogenetics and Evolution, 43(2): 567-582.

Fouquet, A.; Gilles, A.; Vences, M.; Marty, C.; Blanc, M. \& Gemmell, N.J. 2007b. Underestimation of species richness in neotropical frogs revealed by mtDNA analyses. PLoS One, 2: 1-10.

Fouquet, A.; Courtois, E.A.; Baudain, D.; Lima, J.D.; Souza, S.M.; Noonan, B.P. \& Rodrigues, M.T. 2015. The trans-riverine genetic structure of 28 Amazonian frog species is dependent on life history. Journal of Tropical Ecology, 31(4): 361-373

Fouquette Jr., M.J. \& Delahoussaye, A.J. 1977. Sperm morphology in the Hyla rubra group (Amphibia, Anura, Hylidae), and its bearing on generic status. Journal of Herpetology, 11: 387-396.

Fouquette Jr., M.J. \&. Pyburn, W.F. 1972. A new Colombian treefrog of the Hyla rubra complex. Herpetologica, 28: 176-181.

Freitas, M.0. \& Toledo, L.F. 2020. Treefrogs with distinct advertisement calls produce similar territorial signals. Bioacoustics, 1-13.

Frost, D.R. 2020. Amphibian Species of the World: an Online Reference. Version 6.0. American Museum of Natural History, New York, USA. Available: http://research.amnh.org/herpetology/amphibia/index.html. Access: 10/2020.

Gallardo, J.M. 1961. Hyla strigilata Spix e Hyla squalirostris A. Lutz en la República Argentina; y algunas observaciones sobre otros anfibios del grupo de Hyla rubra Daudin. Comunicaciones del Museo Argentino de Ciencias Naturales "Bernardino Rivadavia" Ciencias Zoológicas, 3: 145-158.

Glaw, F. \& Franzen, M. 2006. Type catalogue of amphibians in the Zoologische Staatssamlung München. Spixiana, 29(2): 153-192.

Goloboff, P.A. \& Catalano, S.A. 2016. TNT version 1.5, including a full implementation of phylogenetic morphometrics. Cladistics, 32(3): 221-238.

Goloboff, P.A.; Farris, J.S. \& Nixon, K.C. 2008. TNT, a free program for phylogenetic analysis. Cladistics, 24(5): 774-786.

Gorzula, S.J. \& Señaris J.C. 1999 "1998". Contribution to the herpetofauna of the Venezuelan Guayana I. A data base. Scientia Guaianae, 8: xvii + 268, pls.

Guarnizo, C.E.; Paz, A.; Munoz-Ortiz, A.; Flechas, S.V.; Mendez-Narvaez, J. \& Crawford, A.J. 2015. DNA barcoding survey of anurans across the Eastern Cordillera of Colombia and the impact of the Andes on cryptic diversity. PLoS One, 10(5): e0127312.

Günther, A. 1858. Catalogue of the Batrachia Salientia in the British Museum. British Museum, London. 160p.

Hall, T.A. 1999. BioEdit: a user-friendly biological sequence alignment editor and analysis program for Windows 95/98/NT. In Nucleic acids symposium series (Vol. 41, № 41, pp. 95-98). [London]: Information Retrieval Ltd., c1979-c2000.

Henderson, R.W. \& Powell, R. 2009. Natural history of West Indian reptiles and amphibians (p. 496). Gainesville: University Press of Florida.

Henle, K. 1991. Ololygon pedromedinae sp. nov., ein neuer Knickzehenlaubfrosch (Hylidae) aus Peru. Salamandra, 27(1-2): 76-82.

Heyer, W.R; Rand, A.S.; Cruz, C.A.G.; Peixoto, 0.L. \& Nelson, C.E. 1990. Frogs of Boracéia. Arquivos de Zoologia, 31: 231-410.
Hoogmoed, M.S. 1979. The herpetofauna of the Guianan region. In: Duellman, W.E. (Ed.). The South American Herpetofauna: its Origin, Evolution, and Dispersal, pp. 241-279. Monograph of the Museum of Natural History, the University of Kansas, 7.

Hoogmoed, M.S. \& Avila-Pires, T.C.S. 2011. On the presence of Scinax pedromedinae (Henle, 1991) (Amphibia: Anura: Hylidae) in Amazonian Brazil and northern Peru. Boletim do Museu Paraense Emílio Goeldi. Série Ciências Naturais, 6(3): 263-271.

Hoogmoed, M.S. \& Gorzula, S. 1979. Checklist of the savanna inhabiting frogs of the El Manteco region with notes on their ecology and the description of a new species of treefrog. Zoologische Mededelingen, 54(13): 183-216.

Hoogmoed, M.S. \& Gruber, U. 1983. Spix and Wagler type specimens of reptiles and amphibians in the Natural History Musea in Munich (Germany) and Leiden (The Netherlands). Spixiana, 9: 319-345.

International Commission on Zoological Nomenclature (ICZN). 1999. International Code of Zoological Nomenclature. International Trust for Zoological Nomenclature, London.

Jansen, M.; Bloch, R.; Schulze, A. \& Pfenninger, M. 2011. Integrative inventory of Bolivia's lowland anurans reveals hidden diversity. Zoologica Scripta, 40(6): 567-583.

Izecksohn, E. \& Carvalho-e-Silva, S.P. de. 2001. Anfibios do Município do Rio de Janeiro. Universidade Federal do Rio de Janeiro, Rio de Janeiro. 148p.

Juncá, F.A. 2006. Diversidade e uso de hábitat por anfíbios anuros em duas localidades de Mata Atlântica, no norte do estado da Bahia. Biota Neotropica, 6(2): 1-17.

Juncá, F.A.; Napoli, M.F.; Nunes, I.; Mercês, E.A. \& Abreu, R.0. 2015. A new species of the Scinax ruber clade (Anura, Hylidae) from the Espinhaço Range, northeastern Brazil. Herpetologica, 71(4): 299-309.

Katoh, K. \& Standley, D.M. 2013. MAFFT multiple sequence alignment software version 7: improvements in performance and usability. Molecular Biology and Evolution, 30(4): 772-780.

Köhler, J.\& Bohme,W. 1996. Anuran amphibians from the region of Pre-Cambrian rock outcrops (inselbergs) in northeastern Bolivia, with a note on the gender of Scinax Wagler, 1830. Revue Française d'Aquariologie, 23: 133-140.

Köhler, J.; Jansen, M.; Rodríguez, A.; Kok, P.J.R.; Toledo, L.F.; Emmerich, M.; Glaw, F.; Haddad, C.F.B.; Rödel, M.O. \& Vences, M. 2017. The use of bioacoustics in anuran taxonomy: theory, terminology, methods, and recommendations for best practice. Zootaxa, 4251: 1-124.

La Marca, E. 2004. Descripción de dos nuevos anfibios del Piedemonte Andino de Venezuela. Herpetotropicos, 1(1): 1-9.

Langone, J.A. \& Cardoso, A.J. 1997. Morfología larval externa de Scinax eringiophila (Gallardo, 1961) (Amphibia, Anura, Hylidae). Comunicaciones Zoológicas del Museo de Historia Natural de Montevideo, 12: 1-9.

Laurenti, J.N. 1768. Specimen Medicum, Exhibens Synopsin Reptilium Emendatum cum Experimentis Circa Venena et Antidota Reptilium Austriacorum. Wien, Joan. Thom. nob. de Trattnern.

León, J.R. 1969. The systematics of the frogs of the Hyla rubra group in Middle America. University of Kansas Publications, Museum of Natural History, 18: 505-545.

León-0choa, J.R. 1975. Desarrollo temprano y notas sobre la historia natural de la larva de Hyla $x$-signata (Amphibia: Hylidae). Caribbean Journal Science, 15(1-2): 57-65.

Lescure, J. \& Marty, C. 2000. Atlas des amphibiens de Guyane. Collection Patrimoines Naturels.

Lima, L.P.; Bastos, R.P. \& Giaretta, A.A. 2005 “2004”. A new Scinax Wagler, 1830 of the S. rostratus group from Central Brazil (Amphibia, Anura, Hylidae). Arquivos do Museu Nacional, Rio de Janeiro, 62(4): 505-512.

Littlejohn, M.J. 2001. Patterns of differentiation in temporal properties of acoustic signals of anurans. In: Ryan, M.J. (Ed.). Anuran Communication. Smithsonian Institution Press, Washington and London. 102-120 pp. 
Lourenço, A.C.C.; Lingnau, R.; Haddad, C.F. \& Faivovich, J. 2019. A New species of the Scinax catharinae group (Anura: Hylidae) from the highlands of Santa Catarina, Brazil. South American Journal of Herpetology, 14(3): 163-176.

Lourenço, A.C.C.; Luna, M.C. \& Pombal Jr., J.P. 2014. A new species of the Scinax catharinae Group (Anura: Hylidae) from Northeastern Brazil. Zootaxa, 3889: 259-276.

Luna, M.C.; Mcdiarmid, R.W. \& Faivovich, J. 2018. From erotic excrescences to pheromone shots: structure and diversity of nuptial pads in anurans. Biological Journal of the Linnean Society, 124(3): 403-446.

Lutz, B. 1951. Nota prévia sobre alguns anfíbios do Alto Itatiaia. O Hospital, Rio de Janeiro, 39(5): 705-707.

Lutz, B. 1968. New brazilian forms of Hyla. Pearce-Sellards Series Texas Memorial Museum, 10: 1-18.

Lutz, B. 1973. Brazilian Species of Hyla. University of Texas Press, Austin \& London. 260p.

Lyra, M.L.; Haddad, C.F.B. \& Azeredo-Espin, A.M.L. 2016. Meeting the challenge of DNA barcoding Neotropical amphibians: polymerase chain reaction optimization and new $\mathrm{COI}$ primers. Molecular Ecolology Resources, 17(5): 966-980.

Magrini, L.; Carvalho-e-Silva, S.P.; Béda, A.F. \& Giaretta, A.A. 2011. Calls of five species of the Scinax ruber (Anura: Hylidae) clade from Brazil with comments of their taxonomy. Zootaxa, 3066(1): 37-51.

Mângia, S.; Carvalho, P.; Pereira, E.A.; Cavalcanti, L.; Simões, C.R. \& Santana, D.J. 2017. Release call of Scinax eurydice (Bokermann, 1968) (Anura, Hylidae) and advertisement call of northern populations. Herpetology Notes, 10: 237-243.

Melo-Sampaio, P.R. \& Souza, M.B. 2015. New and noteworthy distributional records of treefrogs (Anura) from southwestern Amazonia. Check List, 11: 1-7.

Moravec, J.; Tuanama, I.A.; Pérez, P.E. \& Lehr, E. 2009. A new species of Scinax (Anura: Hylidae) from the Area of Iquitos, Amazonian Peru. South American Journal of Herpetology, 4(1): 9-16.

Müller, L. 1927. Amphibien und Reptilien der Ausbeute Prof. Bresslau's in Brasilien 1913-1914. Abhandlungen der Senckenbergischen Naturforschenden Gesellschaft, 40: 257-304.

Müller, L. \& Hellmich, W. 1936. Wissenschaftliche Ergebnisse der Deutschen Gran Chaco-Expedition. Amphibien und Reptilien. I. Amphibia, Chelonia, Loricata. Stuttgart, Strecker und Schröder.

Myers, C.W. \& Duellman, W.E. 1982. A new species of Hyla from Cerro Colorado, and other tree frog records and geographical notes from Western Panama. American Museum Novitates, 2752: 1-32.

Napoli, M.F. \& Caramaschi, U. 1998. Duas novas espécies de Hyla Laurenti, 1768 do Brasil central afins de H. tritaeniata Bokermann, 1965 (Amphibia, Anura, Hylidae). Boletim do Museu Nacional, Nova Série, Zoologia, 391: 1-12.

Nieden, F. 1923. Anura I. Subordo Aglossa und Phanerglossa sectio 1 Arcifera. Das Tierreich, 46: 1-584.

Nogueira, L.; Paim, F.; Diniz, D.; Sole, M.; Affonso, P.; Siqueira, S. \& Sampaio, I. 2015. Cytogenetic analysis of Scinax auratus and Scinax eurydice (Anura, Hylidae) with emphasis on cytotaxonomy. Comparative (ytogenetics, 9(2): 227-236.

Novaes, G. \& Zina, J. 2016. Advertisement call of Scinax camposseabrai (Bokermann, 1968) (Anura: Hylidae), with comments on the call of three species of the Scinax ruber clade. Zootaxa, 4084(2): 258-266.

Nunes, I. \& Pombal Jr., J.P. 2010. A new Scinax Wagler (Amphibia, Anura, Hylidae) from the Atlantic Rain Forest remains of southern State of Bahia, North-eastern Brazil. Amphibia-Reptilia, 31(3): 347-353.

Nunes, I.\& Pombal Jr., J.P. 2011. A new snouted treefrog of the speciose genus Scinax Wagler (Anura, Hylidae) from northeastern Brazil. Herpetologica, 67(1): 80-88.
Nunes, I.; Carvalho Jr., R.R. \& Pereira, E.G. 2010. A new species of Scinax Wagler (Anura: Hylidae) from Cerrado of Brazil. Zootaxa, 2514(1): 24-34.

Nunes, I.; Kwet, A. \& Pombal Jr., J.P. 2012. Taxonomic revision of the Scinax alter species complex (Anura: Hylidae). Copeia, 2012: 554-569.

Ouboter, P.E. \& Jairam, R. 2012. Amphibians of Suriname. Leiden, Brill, Boston. $376 \mathrm{p}$.

Palumbi, S.R.; Martin, A.; Romano, S.; McMillan, W.0.; Stice, L. \& Grabawski, $G$. 1991. The Simple Fool's Guide to PCR, Version 2.0. Privately published, compiled by S. Palumbi, University of Hawaii: Honolulu.

Papavero, N. 1971. Essays on the history of neotropical dipterology. Museu de Zoologia, Universidade de São Paulo. 446p.

Peters, W.C.H. 1872. Über die von Spix in Brasilien gesammelten batrachier des Königl. Naturalienkabinets zu München. Monatsberichte der königlich Akademie der Wissenschaften zu Berlin, 1872: 196-227.

Pimenta, B.V.S.; Faivovich, J. \& Pombal Jr., J.P. 2007. On the identity of Hyla strigilata Spix, 1824 (Anura; Hylidae): redescription and neotype designation for a "ghost" taxon. Zootaxa, 1441(1): 35-49.

Pombal Jr., J.P.; Haddad, C.F.B. \& Kasahara, S. 1995a. A new species of Scinax (Anura: Hylidae) from southeastern Brazil, with comments on the genus. Journal of Herpetology, 29: 1-6.

Pombal Jr., J.P.; Bastos, R.P. \& Haddad, C.F.B. 1995b. Vocalizações de algumas espécies do gênero Scinax (Anura, Hylidae) do sudeste do Brasil e comentários taxonômicos. Naturalia, 20: 213-225.

Pombal Jr., J.P.; Bilate, M.; Gambale, P.G.; Signorelli, L. \& Bastos, R.P. 2011. A new miniature treefrog of the Scinax ruber clade from the Cerrado of central Brazil (Anura: Hylidae). Herpetologica, 67(3): 288-299.

Pugliese, A.; Baêta, D. \& Pombal Jr., J.P. 2009. A new species of Scinax (Anura: Hylidae) from rocky montane fields in southeastern and central Brazil. Zootaxa, 2269: 53-64.

Pugliese, A.; Pombal Jr., J.P. \& Sazima, I. 2004. A new species of Scinax (Anura: Hylidae) from rocky montane fields of the Serra do Cipó, Southeastern Brazil. Zootaxa, 688(1): 1-5.

Pyburn, W.F. 1973. A new hylid frog from the Llanos of Colombia. Journal of Herpetology, 7: 297-301.

Pyburn, W.F. 1992. A new tree frog of the genus Scinax from the Vaupes River of northwestern Brazil. The Texas Journal of Science, 44(4): 405-411.

Pyburn, W.F. 1993. Anew species of dimorphic tree frog, genus Hyla (Amphibia: Anura: Hylidae), from the Vaupés River of Colombia. Proceedings of the Biological Society of Washington, 106(1): 46-50.

Pyburn, W.F. \& Fouquette, M.J. 1971. A new striped treefrog from Central Colombia. Journal of Herpetology, 5: 97-101.

Rada de Martinez, D. 1981. Renacuajos de algunos anfibios de Clarines (Edo. Anzoategui, Venezuela). Memorias de la Sociedad de Ciencias Naturales La Salle, 41 (115): 58-75.

Rambaut, A. 2016. FigTree 1.4.3 software. Institute of Evolutionary Biology, University Edinburgh.

Ramo, C. \& Busto, R. 1990 "1989". Inventario herpetológico (Anfibios y Reptiles) de las sabanas inundables del Módulo Fernando Corrales (Mantecal), Estado Apure. Memorias de la Sociedad de Ciencias Naturales La Salle, 49/50: 287-308.

Rivero, J.A. 1961. Salientia of Venezuela. Bulletin of the Museum of Comparative Zoology, Harvard College, 126: 1-207.

Rivero, J.A. 1969. Sobre la Hyla rubra Laurenti y la Hyla x-signata Spix (Amphibia, Salientia). Memorias de la Sociedad de Historia Natural La Salle, 29: 108-119.

Rivero-Blanco, C. \& Dixon, J.R. 1979. Origin and distribution of the herpetofauna of the dry lowland regions of Northern South America. In: Duellman, W.E. (Ed.). The South American Herpetofauna: Its Origin, evolution, and Dispersal. pp. 281-298. Monograph of the Museum of Natural History, the University of Kansas, 7. 
Rodrigues, M.T.; Caramaschi, U. \& Mijares, A. 2010. Scinaxx-signatus. The IUCN Red List of Threatened Species 2010: e.T56005A11404900. Available: https://doi.org/10.2305/IUCN.UK.2010-2.RLTS.T56005A11404900.en. Access: 09/2020.

Ron, S.R.; Duellman, W.E.; Caminer, M.A. \& Pazmi, D. 2018. Advertisement calls and DNA sequences reveal a new species of Scinax (Anura: Hylidae) on the Pacific lowlands of Ecuador. PLoS One, 13(9): 1-26.

Sabaj, M.H. 2019. Standard symbolic codes for institutional resource collections in herpetology and ichthyology: an online reference. Version 7.1. Available: https://asih.org/standard-symbolic-codes/ about-symbolic-codes.

Savage, J.M. \& Heyer, W.R. 1967. Variation and distribution in the tree-frog genus Phyllomedusa in Costa Rica, central America a. Beitrage zur Neotropischen Fauna, 5(2): 111-131.

Señaris, J.C. \& Rojas-Runjaic, F.J.M. 2020. Amphibians and reptiles of Venezuelan Guayana: Diversity, biogeography and conservation. In: Rull, V. \& Carnaval, A.C.0.Q. (Eds.). Neotropical Diversification: Patterns and Processes. Switzerland, Springer Nature. 571-633 pp.

Señaris, J.C.; Lampo, M.; Rojas-Runjaic, F.J.M. \& Barrio-Amorós, C.L. 2014. Guía ilustrada de los anfibios del Parque Nacional Canaima, Venezuela. Ediciones IVIC, Instituto Venezolano de Investigaciones Científicas (IVIC). Caracas, Venezuela. $264 \mathrm{pp}$.

Sichieri, G.R.; Gordo, M. \& Nunes, I. 2019. Posição taxonômica de populações topotípicas das variedades de Scinax $x$-signatus para a Amazônia brasileira (Anura, Hylidae, Scinaxinae). Anais do Encontro Nacional de Pós Graduação, 3(1): 27-31.

Silva, G.R.; Santos, C.L.; Alves, M.R.; Sousa, S.D.V. \& Annunziata, B.B. 2010. Anfíbios das dunas litorâneas do extremo norte do Estado do Piaú, Brasil. Sitientibus. Série Ciencas Biologicas. Revista da Universidade Estadual de Feira de Santana, 7: 334-340.

da Silva, H.R. 1998. Phylogenetic relationships of the family Hylidae with emphasis on the relationships within the subfamily Hylinae (Amphibia: Anura). Ph.D. dissertation, Department of Systematics and Ecology, University of Kansas.

Spix, J.B. d. 1824. Animalia nova sive species novae Testudinum et Ranarum, quas in itinere per Brasiliam annis MDCCCXVII-MDCCCXX jussu et auspiciis Maximiliani Josephi I. Bavariae Regis, Typis Franc. Seraph. Hübschmanni, Monachii, XXXIX + 53 pp.
Sturaro, M.J. \& Peloso, P.L.V. 2014. A new species of Scinax Wagler, 1830 (Anura: Hylidae) from the middle Amazon River basin, Brazil. Papéis Avulsos de Zoologia, 54(2): 9-23.

Suárez, A. \& Lynch, J.D. 2011. Clave ilustrada de los renacuajos en las tierras bajas al oriente de los Andes, con énfasis en Hylidae. Caldasia, 33(1): 235-270.

Swofford, D.L. 2002. PAUP*. Phylogenetic Analysis Using Parsimony (*and other methods). Sunderland, Sinauer Associates.

Taboada, C.; Brunetti, A.E.; Lyra, M.L.; Fitak, R.R.; Soverna, A.F.; Ron, S.R.; Lagorio, M.G.; Haddad, C.F.B.; Norberto, P.L.; Johnsen, S.; Faivovich, F.; Chemes, L.B. \& Bari, S.E. 2020. Multiple origins of green coloration in frogs mediated by a novel biliverdin-binding serpin. Proceedings of the National Academy of Sciences, 117(31): 18574-18581.

Tárano, Z. 2010. Advertisement calls and calling habits of frogs from a flooded savanna ofVenezuela. South American Journal of Herpetology, 5(3):221-240.

Ugueto, G.N. \& Rivas-Fuenmayor, G.A. 2010. Amphibians and Reptiles of Margarita, Coche and Cubagua. Frankfurter Contributions to Natural History volume 46. Frankfurt am Main: Edition Chimaira. 350p.

Vacher, J.-P.; Chave, J.; Ficetola, F.; Sommeria-Klein, G.; Tao, S.; Thébaud, C.; Blanc, M.; Camacho, A.; Cassimiro, J.; Colston, T.J.; Dewynter, M.; Ernst, R.; Gaucher, P.; Gomes, J.0.; Jairam, R.; Kok, P.J.R.; Dias Lima, J.; Martinez, Q.; Marty, C.; Noonan, B.P.; Nunes, P.M.S.; Ouboter P.; Recoder, R.; Rodrigues, M.T.; Snyder, A.; Souza, S.M. \& Fouquet, A. 2020. Large-scale DNA-based survey of frogs in Amazonia suggests a vast underestimation of species richness and endemism. Journal of Biogeography, 2020, 00: 1-11.

Vanzolini, P.E. 1981. The scientific and political contexts of the Bavarian Expedition to Brasil. In: Adler, K. (Ed.). Herpetology of Brazil (facsimilar reprint), Society for the Study of Amphibians and Reptiles, Lawrence, p. IX-XXIX.

Wagler, J. 1830. Natürliches System der Amphibien: mit vorangehender Classification der Säugethiere und Vögel: ein Beitrag zur vergleichenden Zoologie. Cotta'schen, München.

Wiens, J.J.; Kuczynski, C.A.; Hua, X. \& Moen, D.S. 2010. An expanded phylogeny of treefrogs (Hylidae) based on nuclear and mitochondrial sequence data. Molecular Phylogenetics and Evolution, 55(3): 871-882.

Wilkinson, J.A.; Matsui, M. \& Terachi, T. 1996. Geographic variation in a Japanese tree frog (Rhacophorus arboreus) revelead by PCR-aided restriction site analysis of mtDNA. Journal of Herpetology, 30(3): 418-423. 


\section{APPENDIX 1}

\section{List of examined species}

S. acuminatus - Brazil: State of Mato Grosso do Sul, Corumbá, Passo do Lontra: CFBH 3330, 4328, Pantanal study base: CFBH 8642. S. alter - Brazil: State of Bahia: Itaúnas: MZUESC 9775, 9777); State of Rio de Janeiro: Duque de Caxias: CHFURG 4910, 4911); State of Espirito Santo: Santa Leopoldina: Alto Crubixá-Mirim: (FBH 1350-1351, Serra: Sítio Gasparini: Carapebus: CFBH 1442, 1484, Área de Proteção Ambiental do Mestre Álvaro: CFBH 10838, Aracruz, Olho D’Água: CFBH 33149. S. auratus - Brazil: State of Bahia: Ilhéus: CFBH 21097, Jequié: CFBH 23662, 27833, MZUESC 11051, 11052, Maragogipe (MZUESC 13029), Maracás: MZUSP 95458-95493, 95593-95599, Uruçuca: CFBH 14629. S. baumgardneri - Venezuela: Territorio Amazonas: Casa de Julián-between Tabana and Caño Chana: KU 129753 (paratype), Puerto Ayacucho: MZUSP 73702 (paratype). S. boesemani - Surinam: Zanderij: MZUSP 73649-73650 (paratypes). Brazil: State of Roraima: Missão Catrimani: MZUSP 68696-68713; State of Pará: Itaituba: Parque Nacional da Amazonia: MZUSP 146897-146899, 58187-58192, Parque Rio Tapajós: MZUSP 56925-56927; State of Amazonas. Manaus: Colosso Reserve - km 32: CFBH 37169-37170. S. boulengeri - Ecuador: Esmeraldas: Cachavi: MZUSP $105074-105077$. Peru: Loreto: Estirón: Rio Ampiyacu: MZUSP 32947, 32856, 34763. Brazil: State of Amazonas: Igarapé Belém: Rio Solimões: MZUSP 34693. S. cabralensis - Brazil: State of Minas Gerais: Joaquim Felício: MNRJ 42884, 42888 (paratypes). S. caldarum - Brazil: State of Minas Gerais: Poços de Caldas: Morro do Ferro: CFBH 14, 6385, 6388, 17545, MZUSP 101565-101566, 117912, Retiro Branco: MZUSP 132582-132587. S. camposseabrai - Brazil: State of Bahia: Fazenda Cana Brava, 10 km E Maracás: MZUSP 74202 (holotype), 73739-73741, 73755, 74203 (paratypes), Maracás: MZUESC 11021, 11024, 11025. S. constrictus - Brazil: State of Goiás: Montes Claros de Goiás: MZUSP 140832-140834, Campo Limpo de Goiás: Fazenda Conceição: CFBH 12514; State of Tocantins: Taguatinga: CFBH 20983-20984, Porto Nacional: 28294, 28904. Scinax cretatus - Brazil: State of Alagoas, Passo do Camaragibe: CFBH 7348, Fazenda Morro: MZUSP 141283-141286; State of Bahia: Maraú (MZUESC 20604; 20605, 20587, 20649, 20650, 20663, 20695). S. crospedospilus - Brazil: State of Rio de Janeiro: Resende: MZUSP 143887-143888, Brejo da Lapa: MZUSP 102416, Petrópolis: MZUSP 143, Itatiaia: Maringá: CFBH 5737; State of São Paulo: Mogi das Cruzes: Parque Natural: MZUSP 138830-138833, Queluz: CFBH 7210, 7224-7225. S. cruentomma - Peru: Loreto: Estirón: Rio Ampiyacu: MZUSP 34872-34880. S. curicica - Brazil: State of Minas Gerais: Serra do Cipó: MZUSP 77103, 56883-56887, 109440-109441, Santana do Riacho: Serra do Cipó: CFBH 30904, Catas Altas: Serra do Caraça: CFBH 38110, Ouro Preto: CFBH 24379. S. cuspidatus Brazil: State of Espírito Santo: Conceição da Barra: Vila de Itaúnas: CFBH 35362. Marataízes: Gomes pond: CFBH 19480, Linhares: Floresta Nacional de Goytacazes: CFBH 26498; State of Rio de Janeiro: Barra de São João: MZUSP 119824-120157, Rio das Ostras: MZUSP 30912-30959, 56126-56174, Tijuca: MZUSP 110701-110702, 118682-118794, Maricá: Restinga de Maricá: (FBH 24626. S. danae - Venezuela: Estado de Bolívar: km 127 on El Dorado-Santa Elena de Uiarén Road: KU 167089-167090 (paratypes). S. dolloi - Brazil: State of Rio de Janeiro, Itatiaia, Mantiqueira Mountain Range: IRSNB 1.017 (syntypes, 2 specimens). S. duartei Brazil: State of Rio de Janeiro: Itatiaia: Brejo da Lapa: CFBH 140-141, 872, 9896. S. elaeochroa - Costa Rica: Cartago: Turrialba: MZUSP 101179-101181, Alajuela: 2 mi NE muelle de Arsenal: MZUSP 101182-101183. S. eurydice - Brazil: State of Bahia: Fazenda Santo Onofre 10 km E of Maracás: MZUSP 74213 (holotype), 74214-74215 (paratypes), 73732-73733 (paratypes), Maracás: Fazenda Santo Onofre and Canabrava: CFBH 18806, 23660, Maracás: MZUSP 14048-14052 (paratypes), 59912-59914, MHNJCH 1655, Ilhéus: MZUSP 117827, 117835, Itabela: MHNJCH 385, Itagibá: CHFURG 4958, 4959, 4960, Jequié: MHNJCH 172, 1353, 1363, Ubaíra MHNJCH 187, 192, Uruçuca: MHNJCH 712, MZUSP 33890, Salvador: MZUSP 8338, Porto Seguro: Fazenda Lafranchini: CFBH 36878; State of Rio de Janeiro: Grão Mogol: CFBH 10237, Petrópolis: CFBH 13937. S. exiguus - Brazil: State of Roraima: Pacaraima: BV8 área: MZUSP 157397-157403, Tepequém: Avião caído trail: MZUSP 157404-157406, Boa Vista: Estação Ecológica Maracá: Lateral aterro trail: MZUSP 157407. Venezuela: Estado de Bolívar, km 144 on the El Dorado-Santa Elena de Uairén Road in the Gran Sabana: KU 167118, 167121 (paratypes). S. fontanarrosai - Brazil: State of Santa Catarina: Campos Novos: CFBH 23842-23843. S. funereus - Brazil: State of Roraima: Porto Velho: UHE Jirau: left margin of Rio Madeira: MZUSP 146109-146111, 152478-152479, 143316-143317, 152850. S. fuscomarginatus - Brazil: State of Mato Grosso: Chapada dos Guimarães: MZUSP 117768-117770, Jaciara: MZUSP 117773-117790; State of Minas Gerais: Lagoa Santa: marsh in the Lagoa Santa-Fernão Dias Road: CFBH 24357-24358, 24360, 24363. S. fuscovarius - Argentina: Misiones: Campo Anexo INTA "Cuartel Rio Victoria": San Vicente: MACN 38646. Brazil: State of Amazonas: Rio Solimões, Igarapé Belém: MZUSP 33261-33263, CFBH 51, 58, 34283, 37081; State of Espirito Santo: Linhares: CFBH 18087; State of Minas Gerais: Lassance: MZUSP 74154 (paralectotype), Fama: CFBH 1869, Jaboticatubas: (FBH 24367, Sacramento: CFBH 34338; State of Goiás: São João D'Aliança: CFBH 6794. S. garbei - Brazil: State of Amazonas: Rio Juruá: MZUSP 277 (holotype); State of Roraima: Porto Velho: UHE Jirau: left margin of Rio Madeira: MZUSP 153299-153300. Peru: Loreto: Estirón: Rio Ampiyacu: MZUSP 32966-32967, 34747-34759. S. granulatus - Brazil: State of Santa Catarina: Florianópolis: MZUSP 136363-136368, Campo Alegre: Fazenda Sequoia: MZUSP 142261, Chapecó: CFBH 3867-3869, Campos Novos: CFBH 24297-24298; State of Paraná: Marmeleiro: CFBH 33374, Ponta Grossa: Parque Estadual Vila Velha: CFBH 39388-39389; State of Rio Grande do Sul: Estação Ecológica do Taim: MZUSP 57535-57539, Rio Grande: Canal da Corsan: CHFURG 79, 80). S. haddadorum - Brazil: State of Mato Grosso: Barra do Garças: Fazenda Água Limpa: MZUSP 152328 (holotype), MZUSP 152188, 152190-152192, 152326-152327, 152329-152331 (paratypes), (FBH 39054-39056 (paratypes). S. hayii - Brazil: State of Rio de Janeiro, Teresópolis: MZUSP 53479-53484, 116492-116493, Parque Nacional Serra dos Órgãos: MZUSP 116484, CFBH 18820, 35543-35544, Nova Friburgo: CFBH 137. S. imbegue - Brazil: State of Santa Catarina: São Bento do Sul: CEPA pond, Distrito do Rio Vermelho: CFBH 36433-36434; State of Paraná: Guaraqueçaba: CFBH 37503-37504, 37507, 37513, 37522. S. juncae - Brazil: State of Bahia: Almadina: MZUESC 14157, Illéus: MZUESC 14237, 19502, 20614, 20615, Itabuna: MZUESC 14243, Ituberá: MZUESC 12898, 13024, Uruçuca: Fazenda Triunfo: CFBH 32425, Fazenda Bom Fim: CFBH 35739-35740, 39443. S. karenanneae - Colombia: Vaupés: near Timbó: UTA-A 3768, 3769 (paratypes). S. lindsayi - Brazil: State of Amazonas: north side of the Vaupés River about 3 km NW of Yapíma, Vaupés. Colombia: UTA-A 4301, 4303 (paratypes). S. madeirae - Brazil: State of Roraima: Porto Velho: MZUSP 73663 (holotype), 73658 (alotype), $73954-73962$ (paratypes), 74487-74490 (paratypes). S. maracaya - Brazil: State of Minas Gerais: Alpinópolis: Fazenda Salto: MZUSP 73696 (paratype), CFBH 16, Itabirito: CFBH 18425, São Roque de Minas: MZUSP 59550. S. montivagus - Brazil: State of Bahia: Mucugê: CFBH 30117-30118, MZUESC 21294, Morro do Chapéu: MZUESC 14895, 14905, Palmeiras: MZUESC 21246, 21253, 21263). S. nasicus - Argentina: Buenos Aires: Ciudad Autónoma de Buenos Aires: MACN 45072-45074, 45082-45083, Baradero: Estancia "El Retoño": MACN 38650; Santa Fe: Departamento de Garay y 9 de Júlio: MACN 45243-45251; Entre Rios: Departamento de Villaguay: Villa Dominguez: Establecimento 116: MACN 45299-45304. Brazil: State of Mato Grosso: Rosário Oeste: MZUSP 124532-124533, Santo Antônio de Leverger: MZUSP 121597; State of Rio Grande do Sul: Três Lagoas: CFBH 14612, Santa Maria: CFBH 21898-21900. S. nebulosus - Brazil: State of Pará: Canaã: CFBH 3644-3646. State of Roraima: Espigão D'Oeste: CFBH 5112; State of Tocantins: Darcinópolis: CFBH 25920. S. onca - BRAZIL: Roraima: Porto Velho: UHE Jirau: left margin of Rio Madeira: MZUSP 146110-146111, 152850. S. pachycrus - Brazil: State of Bahia: Cachoeira: MHNJCH 148, Irajuba: MZUESC 20220, 20221, Jeremoabo: MZUSP 76908-76913, 77686-77692, Maracás: MHNJCH 1651-1654, 1658, MZUSP 76979-76981, 105474-105489, Maracás, Fazendas Santo Onofre and Cana Brava: CFBH 18798, 
19518-19519, Ubaíra: MHNJCH 190; State of Sergipe: Itabaiana: CFBH 13314, Serra de Itabaiana: MZUSP 72521-72524. S. pedromedinae - Brazil: State of Rondônia: Porto Velho: UHE Jirau: left margin of Rio Madeira: MZUSP 146181-146184, 151253-151255, 151837, Caiçara: 151546-151548, 153077-153079, 15330. S. perereca - Brazil: State of São Paulo: Ribeirão Branco: MZUSP 69637-69639, CFBH 37727, Ribeirão Branco: Fazenda São Luís: MZUSP 103320, 103322, CFBH 2225, 2335, 2501, 30918, Eldorado: Fazenda Tiatá: MZUSP 152921-152922, Parque Estadual Jacupiranga: Nucleo Cedro-Barra: MZUSP 135485, Ibiuna: Parque Estadual Jurupará: MZUSP 141682-141685, 141676-141678, São Miguel do Arcanjo, Parque Estadual de Carlos Botelho: MZUSP 136120-136123. S. pinima - Brazil: State of Minas Gerais: Serra do Cipó km 132: MZUSP 73668 (holotype), 73859-73863 (paratypes), Santana do Riacho: Serrado Cipó: (FBH 35054, 39978. S. proboscideus - Brazil: State of Amapá: Serra do Navio: MZUSP 105084. S. quinquefasciatus - Ecuador: Pichincha: Centro Científico Rio Palenque: MZUSP 55806-55811, 55792-55800. S. rossaferesae - Brazil: State of Paraná: Jaguariaíva: Parque Estadual do Cerrado: (FBH 21027 (holotype), Tibagi: Parque Estadual Guartelá: MZUSP $157140-157142$ (paratypes), MHNCI 9226-9228 (paratypes), Ponta Grossa: Parque Estadual Vila Velha: MHNCI 9841, 9843-9844 (paratypes), CFBH 39390, 39391 (paratypes). S. rostratus - Panama: Canal Zone: MZUSP 107765. S. ruber - Surinam: Langamankondre: MZUSP 31588-31818, 31829-31957, 32859. Brazil: State of Acre: Cruzeiro do Sul: CFBH 26214-26215. S. rupestris - Brazil: State of Goiás: Chapada dos Veadeiros: MZUSP 112877 (holotype), MZUSP 112859-112876, 112878, 112880 (paratypes), CHUNB 72964-72965, 73653 (paratypes). S. similis - Brazil: State of Bahia: Caetité: Alto da Serra Sete Quedas: UFMG 5859, Camamu: MZUESC 20599, 20733, 20760), Magé: CHFURG 4961, 4962, 4963, Maraú, MZUESC 20688, 20697, 20702; State of Rio de Janeiro: Angra dos Reis: CFBH 5764, Manguinhos: MZUSP 73688 (paratype), USNM 97319, 97324, 97351 (paratypes), MZUSP 3899-3918, 9876-9884, llha do Governador: MZUSP 20907, São João da Barra: Grussaí: CFBH 5018-5019; State of Espírito Santo: Aracruz: CFBH 4030-4031, Conceição da Barra: CFBH 4156. S. staufferi - Panama: Canal Zone: MZUSP 113238. México: Tamaulipas: Old Morelos: MZUSP 113237; Campeche: Escarrega: MZUSP 113239, Encarnación: MZUSP 5311-5314, Guerrero: La Venta: MZUSP 5315. S. sugillatus - Ecuador: Pichincha: Scientific Center Rio Palenque: MZUSP 55608-55615. S. squalirostris - Brazil: State of São Paulo: São José do Barreiro: Serra da Bocaina: CFBH 21982, 28780, 30886, 35249. Uruguay: Maldonado: 15 km NE São Carlos: MZUSP 6482 (paratype of Hyla evelynae). S. tigrinus - Brazil: Distrito Federal, Brasília: Fazenda Água Limpa: CFBH 22799. State of Minas Gerais, Buritis: UFMG-A 11565-11567. S. x-signatus - Brazil: State of Bahia: Ilhéus, Salobrinho: UESC: CFBH 44688 (neotype), Ilhéus: Salobrinho: Condomínio Parque Universitário: MZUESC 20683, Caetité: Povoado Senote: CFBH 21071, Contendas do Sincorá: Floresta Nacional Contendas do Sincorá: MHNJCH 1014, Irajuba: Fazenda Lagoa Nova: CFBH 44687, Maracás: Fazendas Santo Onofre and Cana Brava: CFBH 18797, Maracás: near Fazendas Santo Onofre and Cana Brava: MHNJCH 1701, Maracás: Assentamento do Cumbe: MHNJCH 1698-1700, Morro do Chapéu: CPRM: MZUESC 14890, 14891, 14893, Potiraguá: MZUESC 15894, 17503, Sebastião Laranjeiras: UFMG 4787; State of Ceará: Ubajara: CFBH 15874, 15875; State of Pernambuco: Sanharó: CFBH 20856, Fernando de Noronha: CFBH 19668. S. wandae - Colombia: Departamento Meta: 2 km NNE of Villavicencio: KU 131717 (paratype). 


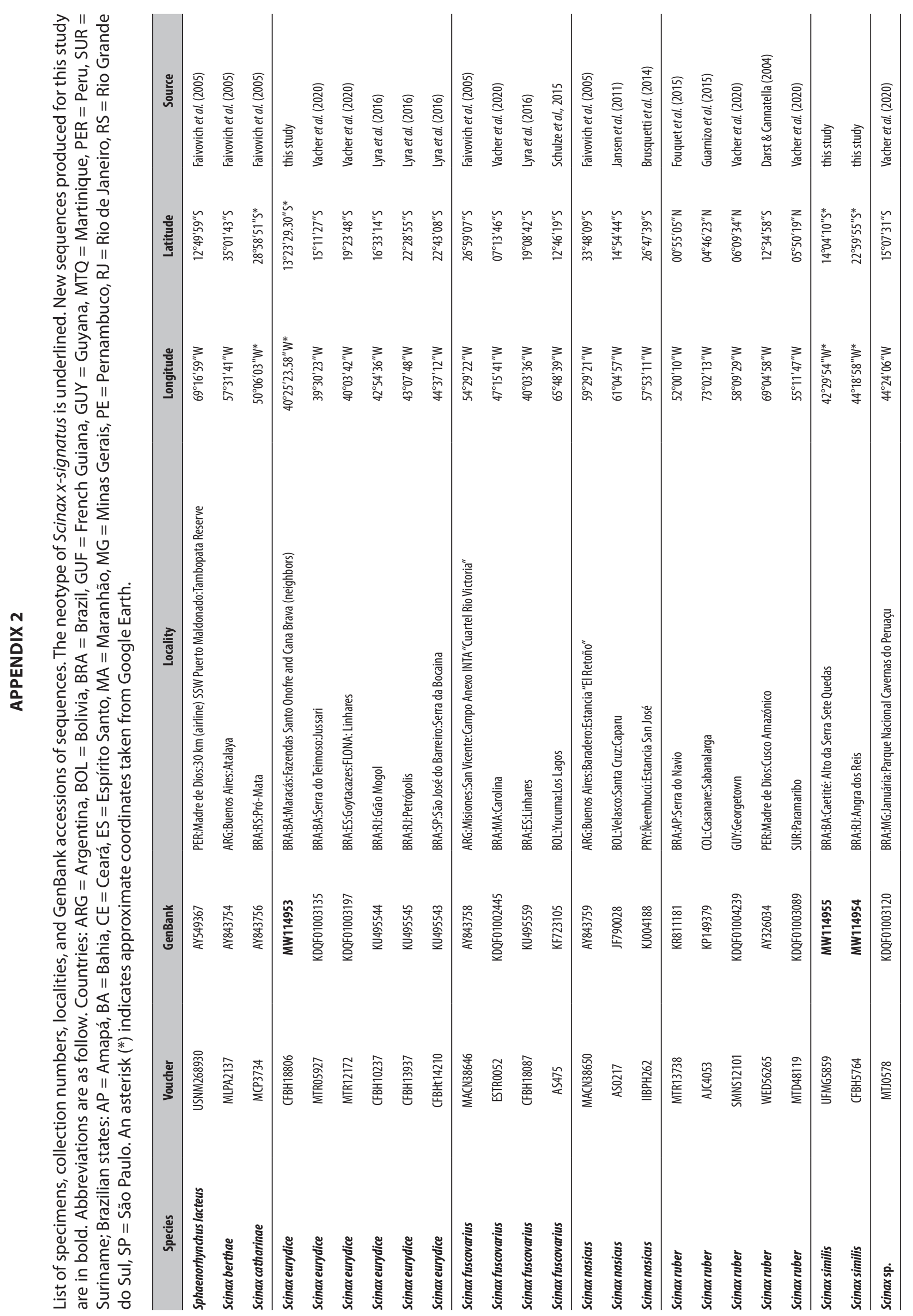




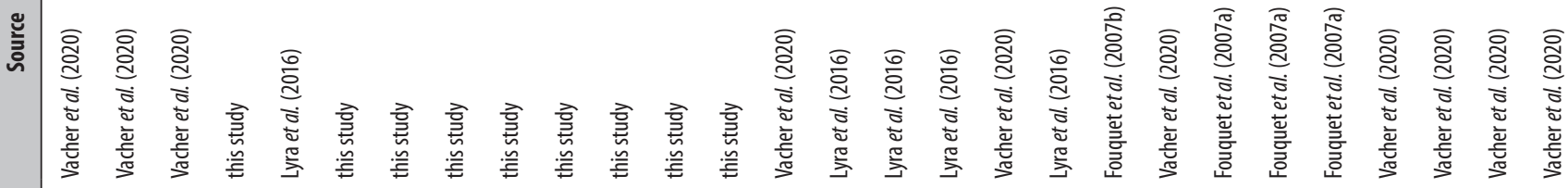

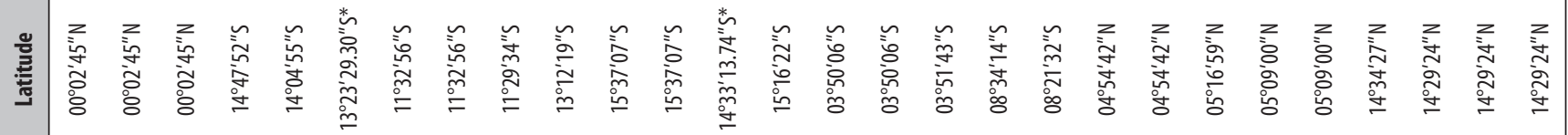

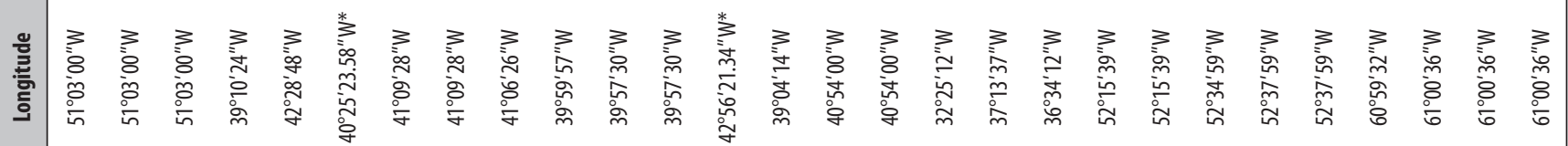

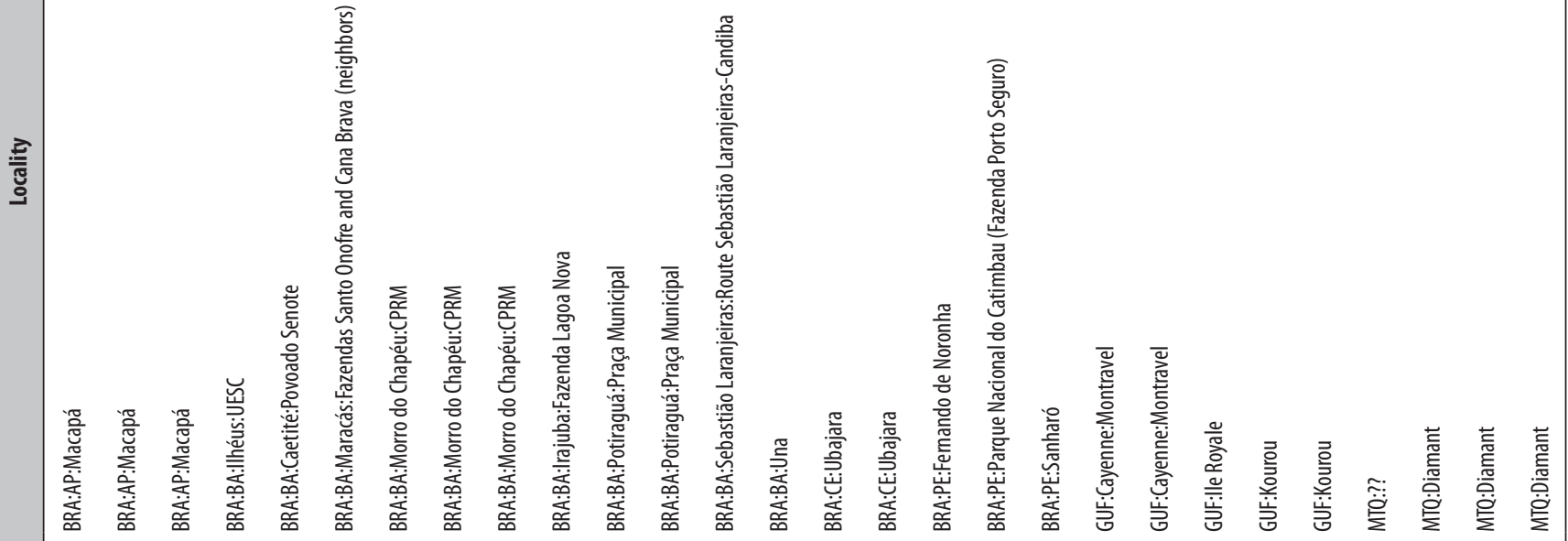

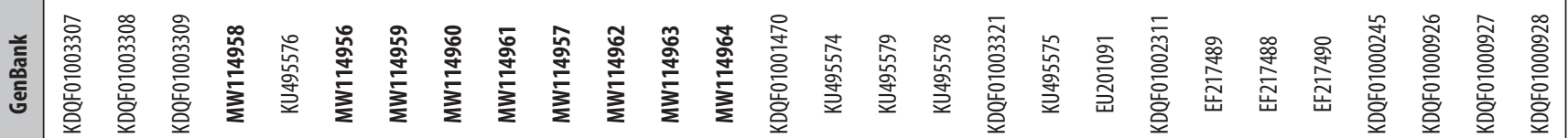

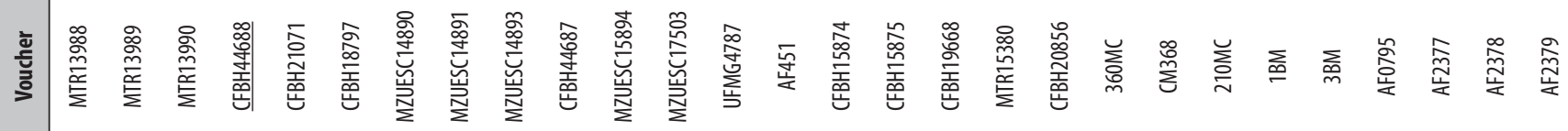

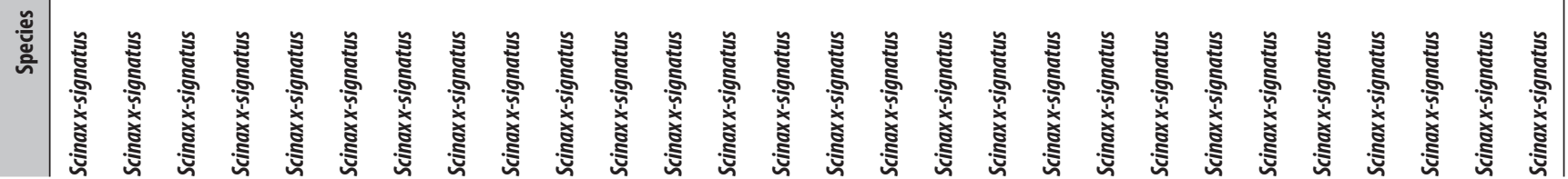

